\title{
Influence of sex and maturity state on trace elements content in liver and muscle of the Scianidae Totoaba macdonaldi
}

\author{
Lia C Méndez-Rodríguez ${ }^{\text {Equal first author, } 1}{ }^{1}$, Berenice Hernández-Aguilar ${ }^{1}$, Juan A de Anda-Montañez ${ }^{2}$, Eduardo F Balart ${ }^{2}$, \\ Martha J Román-Rodríguez ${ }^{3}$, Tania Zenteno-Savín Corresp. Equal first author, 1 \\ 1 Programa de Planeación Ambiental y Conservación, Centro de Investigaciones Biológicas del Noroeste, S.C., La Paz, Baja California Sur, Mexico \\ 2 Programa de Ecología Pesquera, Centro de Investigaciones Biológicas del Noroeste, S.C., La Paz, Baja California Sur, Mexico \\ 3 Comisión de Ecología y Desarrollo Sustentable del Estado de Sonora, San Luis Rio Colorado, Sonora, Mexico \\ Corresponding Author: Tania Zenteno-Savín \\ Email address: tzenteno04@cibnor.mx
}

Background. The fish Totoaba macdonaldi is endemic to the Upper Gulf of California. Its migratory movements involve sites with high levels of trace elements in the environment that can accumulate in tissues. In this study, lead $(\mathrm{Pb})$, copper ( $\mathrm{Cu})$, cadmium $(\mathrm{Cd})$, zinc $(\mathrm{Zn})$ and iron $(\mathrm{Fe})$ concentrations in male and female totoaba liver and muscle were quantified at various sexual maturity stages along the species' geographic distribution.

Methods. Generalized linear models were used to explore associations between trace element concentrations and season of the year, sex/maturity stage, and total fish length.

Results. No detectable Pb concentrations were recorded in liver or muscle; $\mathrm{Cu}, \mathrm{Cd}, \mathrm{Zn}$ and Fe contents in totoaba liver and muscle were typical of fish inhabiting areas with no contamination issues and are within international maximum permissible levels for human consumption. Variations in the content of $\mathrm{Cd}$, $\mathrm{Cu}, \mathrm{Zn}$ and $\mathrm{Fe}$ in liver of totoaba seem to be more related to the feeding and reproductive physiology of this species than as result of environmental exposure. Results suggest that consumption of totoaba muscle does not pose a public health risk. Furthermore, depending on the sex/maturity stage of totoaba, this fish's muscle may provide approximately $70 \% \mathrm{Cu}, 60 \% \mathrm{Zn}$ and $100 \% \mathrm{Fe}$ of the recommended dietary reference intake. 
1 Influence of sex and maturity state on trace elements content

2 in liver and muscle of the Scianidae Totoaba macdonaldi

3

4

Lia Celina Méndez-Rodríguez ${ }^{1}$, Berenice Hernández-Aguilar ${ }^{1}$, Juan Antonio de AndaMontañez ${ }^{2}$, Eduardo F. Balart², Martha Judith Román-Rodríguez ${ }^{3}$, Tania Zenteno-Savín ${ }^{1 *}$

${ }^{1}$ Programa de Planeación Ambiental y Conservación, Centro de Investigaciones Biológicas del Noroeste, S.C. (CIBNOR), La Paz, Baja California Sur, México.

${ }^{2}$ Programa de Ecología Pesquera, Centro de Investigaciones Biológicas del Noroeste, S.C. (CIBNOR), La Paz, Baja California Sur, México.

${ }^{3}$ Comisión de Ecología y Desarrollo Sustentable del Estado de Sonora. San Luis Rio Colorado, Sonora. México. C.P. 83440.

*Corresponding Author

Tania Zenteno-Savín, Ph.D.

Centro de Investigaciones Biológicas del Noroeste, S.C. Instituto Politécnico Nacional 195. Col. Playa Palo de Santa Rita Sur. La Paz, Baja California Sur. 23096, México

E-mail address: tzenteno04@cibnor.mx

Phone number: +52 (612) 123-8502

\section{Abstract}

Background. The fish Totoaba macdonaldi is endemic to the Upper Gulf of California. Its migratory movements involve sites with high levels of trace elements in the environment that can accumulate in tissues. In this study, lead $(\mathrm{Pb})$, copper $(\mathrm{Cu})$, cadmium $(\mathrm{Cd})$, zinc $(\mathrm{Zn})$ and iron (Fe) concentrations in male and female totoaba liver and muscle were quantified at various sexual maturity stages along the species' geographic distribution.

Methods. Generalized linear models were used to explore associations between trace element concentrations and season of the year, sex/maturity stage, and total fish length.

Results. No detectable $\mathrm{Pb}$ concentrations were recorded in liver or muscle; $\mathrm{Cu}, \mathrm{Cd}, \mathrm{Zn}$ and Fe contents in totoaba liver and muscle were typical of fish inhabiting areas with no contamination issues and are within international maximum permissible levels for human consumption. Variations in the content of $\mathrm{Cd}, \mathrm{Cu}, \mathrm{Zn}$ and $\mathrm{Fe}$ in liver of totoaba seem to be more related to the feeding and reproductive physiology of this species than as result of environmental exposure. Results suggest that consumption of totoaba muscle does not pose a public health risk. Furthermore, depending on the sex/maturity stage of totoaba, this fish's muscle may provide approximately $70 \% \mathrm{Cu}, 60 \% \mathrm{Zn}$ and $100 \% \mathrm{Fe}$ of the recommended dietary reference intake.

\section{Introduction}


Totoaba macdonaldi (Gilbert, 1890), commonly known as totoaba (Page et al., 2013), is an endemic fish found in the Gulf of California. Totoaba has a long life of up to 25 years (Román Rodríguez \& Hammann, 1997) and late sexual maturity with an average size at first reproduction of 1,240 mm (De Anda-Montañez et al., 2013). It is a highly selective piscivorous predator that feeds primarily on anchoveta (Cetengraulis mysticetus) and, to a lesser extent, on the silverside of the genus Colpichthys as well as several species of mollusks (De Anda-Montañez et al., 2013). Among the Sciaenidae inhabiting this region, T. macdonaldi displays the greatest size and weight, with up to two meters in length and weighing over $100 \mathrm{~kg}$ (Guevara, 1990; CisnerosMata et al., 1997; Román Rodríguez \& Hammann, 1997). These attributes make it attractive for fishing. In fact, totoaba fishery was important in the first half of last century in the Gulf of California, yielding over 2000 tons in 1942; however, in the 1970's catches decreased to a minimum and the Mexican government declared a permanent ban since 1975 (Arvizu Martínez, 1987; Flanagan \& Hendrickson, 1976). In the last decade, techniques for the aquaculture (mariculture) of totoaba have been developed (Rueda-López et al., 2011; True et al., 1997) and, due to its organoleptic properties, totoaba has become a highly sought-after item in restaurants. Establishing base line trace elements concentration in muscle of totoaba is relevant to characterize and improve the knowledge about their biology.

Trace element content in organisms depends on the species' capacity to regulate metal (e.g., copper $(\mathrm{Cu})$, zinc $(\mathrm{Zn})$ ) concentration and, within tissues, is associated to the specific tissue's function and enzymatic makeup (Hamza-Chaffai et al., 1995). Sex and reproductive stage have a significant effect in the concentrations of trace elements in marine organisms. In marine and freshwater female fish, liver Zn content linked to metallothionein increases during reproduction, potentially aiding vitellogenesis and the synthesis of estradiol-17 (Thompson et al., 2001). The demand for $\mathrm{Zn}$ and $\mathrm{Cu}$ increases during embryonic and neonatal development (Olsson et al., 1987; Thompson et al., 2002). During the annual reproductive cycle of the rainbow trout, Salmo gairdneri $\mathrm{Cu}$ levels in livers from male fishes were higher than those observed in the females and the $\mathrm{Cu}$ levels in males also showed larger fluctuations than females (Olsson et al. 1987). The liver is the primary organ where trace elements are stored and physiologically regulated in fish (Hamza-Chaffai et al., 1995; Roméo et al., 1999). Variability in trace element concentrations is associated to increased accumulation with age, to the geographic location, and to the species' feeding ecology.

Marine organisms found near the coasts of industrial and agricultural centers, as well as those that feed in the upper levels of the food chain, have higher concentrations of trace elements and other contaminants (O'Shea \& Brownell, 1994), although there are alternative suggestions (i.e., Mathews \& Fisher, 2009). In the Gulf of California, trace element concentrations change due to natural phenomena, such as upwelling, and anthropogenic activities, including mining and agriculture. Cadmium is abundant in the Gulf of California and its concentrations are associated to upwelling processes (Ruelas-Inzunza \& Páez-Osuna, 2008). Naturally occurring Cu deposits in Santa Rosalia, that also contain $\mathrm{Zn}$, have been intermittently exploited since the 18th century (Shumilin et al., 2000). Sediment lead (Pb) concentrations in some urbanized areas along the 
coasts are relatively high (up to $89 \mathrm{ppm}$ ) and it has been suggested that these reflect anthropogenic activities (Shumilin et al., 2001). Adult totoabas reach the Upper Gulf of California to spawn from late winter to early spring in areas adjacent to the Colorado River delta, where they remain until late May-early June; then, they migrate southwards to the waters surrounding the large islands (Ángel de la Guarda and Tiburón Islands) (Figure 1). Totoaba remain in this area until late fall (October), when they travel north along the coast of Sinaloa and Sonora to subsequently return to the Colorado River delta in January-February (Arvizu and Chavez, 1972; Cisneros-Mata et al., 1995). Therefore, this species' migration includes sites enriched by trace elements as a result of either natural conditions or anthropogenic inputs and areas where human activities, mostly agriculture, influence water quality (Cadena-Cárdenas et al., 2009).

Trace metals tend to accumulate in marine organisms that are included in the human diet. Some trace elements such as $\mathrm{Zn}, \mathrm{Cu}$, and iron (Fe) are essential elements involved in different metabolic processes; but others, such as $\mathrm{Pb}$ and cadmium $(\mathrm{Cd})$ are non-essential elements that compete with essential elements for enzyme sites. Although less than $20 \%$ of $\mathrm{Pb}$ and $\mathrm{Cd}$ are assimilated in the human body, their half-life in human tissues is around 30 years (EFSA, 2009; EFSA, 2010). Even essential trace elements in excess can cause serious effects to both human and animal health. For example, high intake levels of $\mathrm{Cu}, \mathrm{Zn}$, and $\mathrm{Pb}$ have been related to Alzheimer's disease; Zn and Fe, with Parkinson's disease; Cd may induce kidney dysfunctions, osteomalacia, and reproductive deficiencies, among others (Han et al. 2013; Manea et al. 2020). Due to fish being an essential source of nutrients for humans, but potentially also a source of metals in concentrations that can cause health problems to the consumers (Ruelas-Inzunza et al., 2010; Zamaora-Arellano et al., 2018), it is necessary to perform health risk assessments to identify the adequacy of fish species for human consumption.

The objective of this study was to assess changes on the concentrations of essential elements $(\mathrm{Cu}, \mathrm{Zn}, \mathrm{Fe})$ and toxic elements for humans (such as $\mathrm{Cd}$ and $\mathrm{Pb}$ ) in relation to the sex/maturity stage, season, and habitat in liver and in the edible tissue (muscle) of totoaba. This information can provide support for totoaba aquaculture which can contribute to the protection of this species if it is no longer fished.

\section{Material \& Methods}

\section{Overview of experimental program}

An overview of the experimental program is shown in Figure 2. Totoaba individuals $(\mathrm{n}=144)$ were collected from the Upper Gulf of California in three types of habitats, 1) estuarine, 2) rocky, and 3) continental. Field trips were conducted to collect samples during all seasons (spring, summer, autumn, winter) along the species' distribution; however, fish were not found in summer in any of the sampled sites; in winter and spring totoaba were found in the spawning grounds (estuarine habitat), while specimens sampled in autumn were collected in non-spawning areas (coastal and rocky habitats) (De Anda-Montañez et al., 2013). From each totoaba caught, total length and weight were recorded, and liver $(\mathrm{n}=142)$ and muscle $(\mathrm{n}=144)$ samples, as well 
119

120

121

122

123

124

125

126

127

128

129

130

131

132

133

134

135

136

137

138

139

140

141

142

143

144

145

146

147

148

149

150

151

152

153

154

155

156

157

158

as gonads $(\mathrm{n}=144)$, were collected. Based on the histological analysis of gonads and on gamete development and tissue characteristics sex and maturity stage were defined.

\section{Sample Collection}

Totoaba individuals were collected from the Upper Gulf of California (Figure 1) under scientific collection permits issued by the Mexican government (SGPA/DGVS/02913/10, SGPA/DGVS/05508/11 and SGPA/DGVS/00039/13) based on the research protocol described in the project entitled "Health and Conservation status of the totoaba population (Totoaba macdonaldi) in the Gulf of California: a critically endangered species" (CONABIO: FB1508/HK050/10; CONACYT 2011-01/165376; CIBNOR:137C/EP0.04). This study was performed following the demands, requirements and protocols that are required by the various institutions involved (SGPA/DGVS, CONABIO, CONACYT, CIBNOR). A total of 144 individuals were collected between May 2010 and April 2012. The organisms were collected in three types of habitats; 1) estuarine, which correspond to the area of the Upper Gulf of California and Colorado River Delta Biosphere Reserve, 2) rocky, refers to the area around the Islands, and 3) continental, which refers to the east coast of the Gulf of California in different seasons of the year along the species' distribution across the Gulf of California. Fishing was carried out on board 26-foot vessels with outboard motors. The fishing gears used included gillnets measuring $120 \mathrm{~m}$ long with a mesh size of 10 inches, and fishing rods with no. 5 and 6 hooks; shrimp heads, squid and/or comber were used as bait. The total length and weight of each totoaba caught were recorded. Liver (142) and muscle (144) samples were collected from each fish; samples were separately placed in plastic bags, stored on ice, and transported to the laboratory at CIBNOR for storage at $-80^{\circ} \mathrm{C}$ until analyzed. Gonads $(n=144)$ were also sampled and stored in Davidson's fixative for sex identification and maturity stage determination. Each individual fish was classified as follows, based on the histological analysis of gonads, immature female (IF), mature female (MF), immature male (IM), and mature male (MM). This classification was based on gamete development and the characteristics of the reproductive structures, such as follicles, germinal epithelium, and interfollicular connective tissue (Tyler \& Sumpter, 1996). Fish in which gonads lacked characteristics allowing for the differentiation of ovaries or testicles were classified as undifferentiated (UN).

\section{Trace Elements Analysis}

From each totoaba collected, $5 \mathrm{~g}$ of muscle and $5 \mathrm{~g}$ of liver were oven-dried separately at $70^{\circ} \mathrm{C}$ and subsequently digested with nitric acid $\left(\mathrm{HNO}_{3}\right)$ and $\mathrm{H}_{2} \mathrm{O}_{2}$ in a microwave (Mars 5x, CEM, Matthew, NC, USA). After acid digestion, $1 \mathrm{~mL}$ of hydrochloric acid $(\mathrm{HCl})$ was added to each sample and the volume was brought to $50 \mathrm{~mL}$ with deionized water (Cadena-Cárdenas et al., 2009; Barrera-García et al., 2012). Copper, Cd, Zn, Fe, and Pb concentrations were determined by atomic absorption spectrophotometry (GBS Scientific AVANTA, Dandenong, Australia) using an air/acetylene flame. Each sample was tested in triplicate. High-purity reagents were used in all cases and blanks were analyzed in parallel to validate the efficiency of the method 
159

160

161

162

163

164

165

166

167

168

169

170

171

172

173

174

175

176

177

178

179

180

181

182

183

184

185

186

187

188

189

190

191

192

193

194

195

196

197

198

(Barrera-García et al., 2012). A quality control sample was analyzed at an interval of every ten samples to ensure the quality of analyses in addition to blanks and calibration standard solutions. Certificate reference material (DORM-2, National Research Council of Canada) was also analyzed in each ten samples run as a quality control (Jara-Marini et al., 2009); a 93\% - 106\% recovery rate was calculated. The detection limits and quantification limits $\left(\mu \mathrm{g} \mathrm{g}^{-1}\right)$ were as follows, respectively: $\mathrm{Cd}: 0.01$ and $0.02 ; \mathrm{Pb}: 0.07$ and $0.10 ; \mathrm{Cu}: 0.017$ and $0.020 ; \mathrm{Zn}: 0.021$ and 0.060; Fe: 0.65 and1.35. All the results are expressed in dry weight.

\section{Nutritional and risk assessment}

The estimated daily intake (EDI, mg trace element $\mathrm{kg}^{-1} \mathrm{BW}$ day-1) of $\mathrm{Cu}, \mathrm{Cd}, \mathrm{Zn}$ and $\mathrm{Fe}$ when totoaba muscle is consumed was calculated as follows in Equation 1 (Bilandžić et al., 2014):

$$
\mathrm{EDI}=(\mathrm{Cm} * \mathrm{CR}) / \mathrm{BW}
$$

(Equation 1)

where:

$\mathrm{Cm}=$ mean concentration of trace metals in the muscle of totoaba, expressed in fresh weight $(\mu \mathrm{g}$ $\left.\mathrm{g}^{-1}, \mathrm{fw}\right)$.

$\mathrm{CR}=$ Mean per capita daily consumption rate of fish muscle (in this study, fishermen populations living on the coast of north-western Mexico (130 $\mathrm{g} \mathrm{day}^{-1}$ ) (Zamora-Arellano et al., 2018).

$\mathrm{BW}=$ mean body weight in the general population or subpopulation $(74 \mathrm{~kg}$; Zamora-Arellano et al., 2018).

The contribution of the mean daily consumption of totoaba muscle to the recommended daily intake (RDI) was assessed for the essential elements addressed in this study, including $\mathrm{Cu}: 0.9$ mg day ${ }^{-1}, \mathrm{Zn}: 11 \mathrm{mg} \mathrm{day}^{-1}$ and Fe: $8 \mathrm{mg} \mathrm{day}^{-1}$ person (Trumbo et al., 2001) and RfD (National Academies of Sciences, Engineering, and Medicine, 2017).

The hazard index (HI) for $\mathrm{Cu}, \mathrm{Cd}, \mathrm{Zn}$ and $\mathrm{Fe}$ based on daily ingestion of muscle of totoaba was achieved by deterministic and probabilistic (Monte Carlo simulations) approaches (Sanaei et al., 2020). With the deterministic approach, the contribution of the geometric mean of $\mathrm{Cu}, \mathrm{Cd}, \mathrm{Zn}$ and $\mathrm{Fe}$ concentration found in muscle of totoaba was compared to their respective metal reference dose (RfD). The RfD is an estimate (with uncertainty spanning perhaps an order of magnitude) of a daily oral exposure for an acute duration ( 24 hours or less) to the human population (including sensitive subgroups) that is likely to be without an appreciable risk of deleterious effects during a lifetime (USEPA, 2020). The Environmental Protection Agency (EPA) recommends for $\mathrm{Cu} 0.40 \mathrm{mg} \mathrm{kg}^{-1} \mathrm{day}^{-1}$; $\mathrm{Cd} 0.001 \mathrm{mg} \mathrm{kg}^{-1} \mathrm{day}^{-1}$; $\mathrm{Zn} 0.30 \mathrm{mg} \mathrm{kg} \mathrm{day}^{-1}$; and Fe $0.7 \mathrm{mg} \mathrm{kg}^{-1} \mathrm{day}^{-1}$ (USEPA, 2020). The EPA has not established an RfD for Pb because a "safe" exposure limit for $\mathrm{Pb}$ toxicity is still uncertain (EFSA Panel on Contaminants in the Food Chain (CONTAM), 2010); Korkmaz et al., 2019).

As a probabilistic approach of risk assessment, Monte Carlo simulations (MCS) were performed. MCS recently have been used for environmental health and safety risk assessments associated to metal exposure through water and food (Jia et al., 2018; Chen et al., 2019; Sanaei et al., 2020). MCS reduce the probability of uncertainty caused when only a single point value is 
199

200

201

202

203

204

205

206

207

208

209

210

211

212

213

214

215

216

217

218

219

220

221

222

223

224

225

226

227

228

229

230

231

232

233

234

235

236

237

238

239

used for each variable during the risk assessment (as was calculated deterministically using Equation 1. The distributions of parameters for MCS are listed in Table 1. MCS mainly consist of three steps, (1) introduction and definition of the distribution functions of the variables; (2) inclusion of the formula that will be used to calculate the risk considering also the RfD, and (3) carrying out several simulations generating random numbers of the unknown parameter from a specific probability density function. Each random number simulates a scenario independently. The process is iterative and the results are displayed as a probability curve, where the $\mathrm{X}$ axis represents the simulated variable and the $\mathrm{Y}$ axis represents the probability of occurrence (Chen et al., 2019). In this study, Cristal Ball (11.1.2.4) software from Oracle was used to perform MCS. Iterations for every run were set to 10,000 (Jia et al. 2018; Sanaei et al. 2020; Chen 2019) and Log-normal probability distribution functions for the parameters (Table 1) were employed to generate the cumulative hazard index (Chen et al., 2019) of $\mathrm{Cu}, \mathrm{Zn}, \mathrm{Cd}$ and $\mathrm{Fe}$ associated to the consumption of muscle of totoaba.

Based on the results of the MCS, a sensitivity analysis was conducted by introducing variation in some parameters and their effect over hazard index. The level of sensitivity is shown as contribution to variance (\%) and correlation. This analysis is employed to judge the significance of the input parameters to the risk estimation (Chen et al., 2019; Sanaei et al., 2020).

Aiming to identify potential factors that can influence the concentration of $\mathrm{Cu}, \mathrm{Cd}, \mathrm{Zn}$ and $\mathrm{Fe}$ in liver and muscle, and therefore in the health risk for consumption of totoaba muscle, a principal component analysis (PCA) was performed using TIBCO STATISTICA software ver. 13.3.

\section{Statistical Analysis}

The Shapiro-Wilk's normality and Bartlett's homoscedasticity tests were run. Differences between groups (IF, MF, IM, MM, UN) were examined by means of analysis of variance (ANOVA) followed by post-hoc Tukey's honest significance test (Zar, 1998). Differences were considered significant when $p<0.05$. Statistica 8.0 (StatSoft Inc. Tulsa, OK, USA) software was used to perform all statistical analyses. Results are expressed as mean $\pm \mathrm{SE}$.

Generalized linear models (GLM) were used to explore the variables that may affect muscle and liver Cd levels in the totoaba (dependent variables, Table 2) through simultaneous effects of the independent variables (season of the year, sex/maturity stage, total length, and concentrations of trace elements in liver and muscle of totoaba) (Tables 2 and 3). Two models were fitted to the data; the variables selected as continuous dependent (response) variable in each model were liver $\mathrm{Cd}$ concentration in model 1 , and muscle $\mathrm{Cd}$ in model 2 . In both cases, the dependent variables were modeled assuming a gamma distribution error since no significant differences were obtained from the Chi square test $(p>0.05)$. In the GLM, the season and sex/maturity stage were included as categorical explanatory variables; length and metal concentrations in liver and muscle were included as continuous explanatory variables (Tables 2 and 3). In all cases, the logtype link function was used to relate the dependent variable (liver $\mathrm{Cd}$, muscle $\mathrm{Cd}$ ) with categorical and continuous independent variables. Finally, the models were visually validated 
240 through the residual deviation of observed and predicted values selected based on the proportion

241 of the explained deviance (Murillo-Cisneros et al., 2018), and Akaike's and Bayesian

242 information criteria (AIC and BIC, respectively) (Burnham \& Anderson, 2004; Hobbs \&

243 Hilborn, 2006; Johnson \& Omland, 2004; Zuur et al., 2009).

\section{Results}

246

247

248

249

250

251

252

253

254

255

256

257

258

259

260

261

262

263

264

265

266

267

268

269

270

271

272

273

274

275

276

277

278

279

Table 3 shows trace elements concentrations in muscle and liver of totoaba, grouped by habitat (estuaries, rocky and continental), season (winter, spring and autumn), and sex/maturity stage. In liver, $\mathrm{Cu}$ levels were significantly higher in MF in winter in estuarine habitat than IF, IM, and $\mathrm{UN}$ individuals collected in autumn in continental habitats $(p<0.05)$. Female individuals (mature and immature) in spring had about 3 times lower liver $\mathrm{Cd}$ concentrations compared to IF, IM, and UN specimens collected in autumn in rocky habitat; there were no significant differences between the individuals collected in winter and the totoabas collected in spring (both estuarine and rocky habitats) and autumn (continental habitats) $(p>0.05)$. Female totoabas collected in winter showed significantly higher liver $\mathrm{Zn}$ levels in comparison with their counterparts collected in spring $(p<0.05)$. Mature females in spring from rocky habitat had significantly lower liver Fe as compared to IF and UN collected in autumn from the same habitat $(p<0.05)$ (Table 3). Also, in autumn, significantly higher concentrations of Fe were observed in organisms from rocky versus continental habitats $(p<0.05)$. No detectable $\mathrm{Pb}$ levels $(<0.07 \mu \mathrm{g}$ $\left.\mathrm{g}^{-1}\right)$ were observed in any of the analyzed liver samples.

In totoaba muscle, $\mathrm{Pb}$ levels were below the detection limit $\left(<0.07 \mu \mathrm{g} \mathrm{g}^{-1}\right)$, and only $10 \%$ of the samples showed detectable Cd levels $\left(>0.01 \mu \mathrm{g} \mathrm{g}^{-1}\right)$ (Table 3). No significant differences were observed in muscle $\mathrm{Cu}$ and $\mathrm{Cd}$ levels $(p>0.05)$. Mature males and MF had significantly higher muscle $\mathrm{Zn}$ levels in winter as compared to organisms collected both in spring and autumn in rocky and continental habitats $(p<0.05)$.

Copper, $\mathrm{Zn}$, and Fe concentrations were significantly higher in liver than in muscle ( $p=$ 0.001) (Table 3). While $100 \%$ of liver samples showed detectable $\mathrm{Cu}$ and $\mathrm{Cd}$ levels, these elements were undetectable in muscle in $40 \%$ and $90 \%$ of samples, respectively. Liver $\mathrm{Cu}, \mathrm{Zn}$, and Fe concentrations were approximately up to 40-, 7- and 80-fold higher, respectively, than in muscle.

\section{Health Risk}

Figure 3 shows the $\mathrm{Cu}, \mathrm{Cd}, \mathrm{Zn}$ and $\mathrm{Fe}$ content in muscle of Totoaba macdonaldi relative to the RDI, by sex/maturity stage groups and season (winter, spring, autumn). Consumption of totoaba muscle can provide the human diet with approximately $70 \%$ of $\mathrm{Cu}, 60 \%$ of $\mathrm{Zn}$, and more than $100 \%$ of $\mathrm{Fe}$ of the RDI. In addition, the concentrations of $\mathrm{Cu}, \mathrm{Zn}$ and $\mathrm{Fe}$ in muscle of totoaba are from one to several orders of magnitude below the RfD. Cadmium input from totoaba muscle to the human diet can be from zero to approximately $20 \%$ of the RfD, depending on the fish's sex/maturity stage. No detectable concentrations of $\mathrm{Pb}$ were recorded in muscle of totoaba; therefore, no comparisons to RfD are available. 
The potential health risk to local inhabitants from long-term exposure for $\mathrm{Cu}, \mathrm{Cd}, \mathrm{Zn}$ and Fe in fish muscles of totoaba was assessed deterministically (Sanaei et al., 2020) and through the hazard index (HI) obtained by the probabilistic approach using MCS in adult population. MonteCarlo simulation was introduced to conduct uncertainty through 10,000 iterations for each trace element simulation. The probabilistic distributions of health risk as hazard index (HI) obtained from MCS are demonstrated in Figure 4, including mean, 5th percentile and 95th percentile for each metal. The HI values obtained from probabilistic values (MCS) are lower than those calculated by deterministic approach; $\mathrm{Cu}: 0.08$ vs 0.10 ; Cd: 0.06 vs 0.07 ; Zinc: 0.17 vs 0.21 for Fe 0.10 vs 0.13 , respectively. The percentile values for the HI for all the metals are lower than 1 . In Figure 5 the associated risk given by the $\mathrm{HI}$ of $\mathrm{Cu}, \mathrm{Cd}, \mathrm{Zn}$ and $\mathrm{Fe}$ from totoaba muscle consumption is shown. The contribution of each HI can be arranged in decreasing order as follows $\mathrm{HI}_{\mathrm{Zn}}>\mathrm{HI}_{\mathrm{Fe}}>\mathrm{HI}_{\mathrm{Cu}}>\mathrm{HI}_{\mathrm{Cd}}$. The sensitivity analysis (Table 4) showed that the consumption rate of muscle of totoaba is the parameter that contributes with the highest explanation of the variance of each metal $\mathrm{HI}, 75.4 \%$ in $\mathrm{HI}_{\mathrm{Cu}} ; 82.7 \%$ in $\mathrm{HI}_{\mathrm{Cd}}, 82.7$ en $\mathrm{HI}_{\mathrm{Zn}}$ and $83 \%$ in $\mathrm{HI}_{\mathrm{Fe}}$. Otherwise, the body index has a negative relationship and in the case of totoaba muscle the influence of metal content has the lowest importance in the contribution of the variance.

For qualitative evaluation of clustering behavior of $\mathrm{Cu}, \mathrm{Cd}, \mathrm{Zn}$ and $\mathrm{Fe}$ in liver and muscle of totoaba regarding season, habitat and gonadic state a principal component analysis (PCA) when varimax normalization was applied. The results are shown in Table 5. The PCA of these data indicates their association and grouping in three factors that explain $52.28 \%$ of the variance. Factor 1 contributed $24.60 \%$ of the total variance with the highest loadings of $\mathrm{Cu}_{\text {muscle }}, \mathrm{Cu}_{\text {liver }}$, and $\mathrm{Zn}_{\text {muscle, }}$, that are directly related to winter, estuarine, mature females and mature male, but inversely related to spring, and in less magnitude, to immature organism. Factor 2 contributed $15.88 \%$ of the total variance with the highest loading of $\mathrm{Cd}_{\text {liver }}, \mathrm{Zn}_{\text {liver, }}$ and $\mathrm{Fe}_{\text {liver }}$ that are only associated to autumn and to a lesser extent spring. Factor 3 has the highest loading of $\mathrm{Fe}_{\text {muscle }}$ that is inversely to autumn and to rocky habitat but directly related to continental habitat.

\section{Generalized Linear Models (GLM)}

Due to $\mathrm{Cd}$ being an important element in relation to health risk, GLM were used to explore the variables that may affect the content of $\mathrm{Cd}$ in muscle and liver in totoaba. The first GLM model explains $46 \%$ of the variance (Table 6), fitting the data reasonably well. The ratios of the deviance and Pearson Chi square over the degree of freedom close to 1.0, in particular model 2 , does not show evidence of overdispersion. The model suggests that liver Cd concentration varies inversely with liver $\mathrm{Zn}$ concentration. Other elements measured in liver or muscle samples were not identified as significantly affecting liver $\mathrm{Cd}$ content. However, the winter season and sex/maturity stage and two interactions were significant. The second GLM model (Table 6), which explains $71 \%$ of the variance, suggests that liver $\mathrm{Cd}$ is the only element that significantly affects muscle $\mathrm{Cd}$ concentrations in totoaba. Furthermore, sex/maturity stages and an interaction were significant. Both models were validated using the analysis of residuals (Figure 6), 
320

321

322

323

324

325

326

327

328

329

330

331

332

333

334

335

336

337

338

339

340

341

342

343

344

345

346

347

348

349

350

351

352

353

354

355

356

357

358

359

suggesting that the variance is homogeneous for all the independent variables and that the relationship between the observed and fitted values is nearly linear.

\section{Discussion}

Compared to muscle, liver accumulates a larger concentration of metals because of its detoxifying function and specific metabolic rate, acting as a depot of chemical elements, some of which function as enzyme cofactors (Kalay et al., 1999). This held true for totoaba analyzed in the present study; liver concentrations of $\mathrm{Cu}, \mathrm{Zn}$ and Fe were 40-, 7-, and 80-fold higher than in muscle. The liver is highly active in fish metabolism and, therefore, the liver may accumulate metals to higher levels than other tissues, such as the muscle (Kalay \& Canli, 2000).

In this study, no detectable $\mathrm{Pb}$ levels were recorded in either liver or muscle of totoaba. Other scianid fish, such as Otolithes ruber and Johnius belangerii, also show a low $\mathrm{Pb}$ content relative to other fish species, including Pampus argenteus (Stromateidae), Pomadasys sp. (Haemulidae), Euryglossa orientalis (Soleidae), and Cynoglossus arel (Cynoglossidae) collected in the same sites from the Persian Gulf (Agah et al., 2009; Monikh et al., 2012). In biological systems, trace elements may be either bound to molecules or found as chemical fractions (speciation) that cannot be assimilated by the organism; in which case, trace elements are not bioavailable, can be excreted, and are not bioaccumulated (Bebianno and Langston, 1991). Although $\mathrm{Pb}$ has been reported at high concentrations in invertebrates such as clams (up to $9.2 \pm$ $1.4 \mu \mathrm{g}$ g-1 dry weight) from the Upper Gulf of California (Cadena-Cárdenas et al., 2009), in fishes of this region the levels are characteristic of areas not contaminated by this element (Ruelas-Inzunza \& Paez-Osuna, 2008; Jara-Marini et al., 2009; Ruelas-Inzunza, et al., 2010). Apparently, $\mathrm{Pb}$ does not undergo biomagnification across some food chains in the Gulf of California (Jara-Marini et al., 2009). This may be due to the functional (carboxyl, sulfhydryl) groups to which Pb can bind in mollusk and fish species (Ruelas-Inzunza \& Páez-Osuna, 2008) that may be found as part of the totoaba diet (De Anda-Montañez et al., 2013).

The highest $\mathrm{Cu}$ levels in liver and muscle of totoaba quantified in this study were below $70 \mu \mathrm{g} \mathrm{g}^{-1}$. Natural $\mathrm{Cu}$ deposits are found along the Baja California peninsula, particularly in Santa Rosalia, Baja California Sur. The Cu concentrations in totoaba in this study were found to be similar to those recorded in other fish, such as $O$. ruber (7.5-19.5 $\left.\mu \mathrm{g} \mathrm{g}^{-1}\right)$, J. belangerii (0545$\left.1458 \mu \mathrm{g} \mathrm{g}^{-1}\right)$, Menticirrhus americanus (8.8-18 $\left.\mu \mathrm{g} \mathrm{g}^{-1}\right)$, Micropogonias furneiri (10-122 $\left.\mu \mathrm{g} \mathrm{g}^{-1}\right)$, and Cynoscion guatucupa (22-119 $\mathrm{g} \mathrm{g}^{-1}$ ) (Monikh et al., 2012; Agah et al., 2009; Viana et al., 2005). These $\mathrm{Cu}$ concentrations are considered suitable for human consumption (approximately $120 \mu \mathrm{g} \mathrm{g}^{-1}$ dry weight; $30 \mu \mathrm{g} \mathrm{g}^{-1} \mathrm{ww}$, Viana et al., 2005; Monick et al., 2012) even though in these studies, fish were sampled in areas influenced by wastewater from tanning, chemical, and agricultural industries, or from urban effluents (Agah et al., 2009; Viana et al., 2005). Variations in tissue $\mathrm{Cu}$ levels in sciaenids are attributed to the physiology of each species, rather than to the influence of the environmental conditions in the area where they live (Hamza-Chaffai et al., 1995). In totoaba in this study, significantly higher $\mathrm{Cu}$ content in MF as compared to IF is likely due to $\mathrm{Cu}$ functioning also as a cofactor of cytochrome c oxidase (Kirchgessner et al., 1977); the 
360

361

362

363

364

365

366

367

368

369

370

371

372

373

374

375

376

377

378

379

380

381

382

383

384

385

386

387

388

389

390

391

392

393

394

395

396

397

398

399

400

activity of this enzyme increases in the reproductive stage contributing to meet the additional energy requirements during this process in fishes (Olsson et al., 1987).

Mature female and male totoaba had higher $\mathrm{Zn}$ concentrations in winter than in spring. In the squirrelfish (Sargocentron spiniferum), a reef associated fish, and the euryhaline rainbow trout (Oncorhynchus mykiss), a freshwater fish, liver Zn content bound to metallothionein increases, more so in MF than in MM, during reproduction, potentially aiding vitellogenesis and the synthesis of estradiol-17 $\beta$ (Thompson et al., 2001). The demand for $\mathrm{Zn}$ increases during embryonic and neonatal development (Olsson et al., 1987; Thompson et al., 2002). In spring, Fe content in the liver of MF and MM was almost 50\% the content observed in totoaba collected in winter. This difference in Fe levels could be associated with fasting conditions reported for totoaba in its spawning grounds in the north of the Upper Gulf of California over the winter (De Anda-Montañez et al., 2013). The feeding rate of totoaba adults has been reported to decrease during the reproductive season (Román Rodríguez \& Hammann, 1997).

The Cd concentration in the liver of immature totoaba collected in autumn in rocky habitat was more than three-fold the level in organisms collected in spring $(p<0.05)$. In a study that compared Cd content between J. belangerii (Sciaenidae), Liza abu (Mugilidae), and Euryglossa orientalis (Mugilidae), the sciaenid fish showed significantly higher Cd levels (3.80 $\left.\pm 0.66 \mu \mathrm{g} \mathrm{g}^{-1}\right)$, which was attributed to its feeding habits, because $J$. belangerii lives in close association with sediment, and feeds mainly upon crustaceans, mollusks, and shrimp (Monikh et al., 2012). In autumn, totoaba feeds in the area adjacent to the large islands; the oceanographic conditions in this area foster a high primary productivity, reflected as a high abundance of birds and marine mammals (Hidalgo-González \& Alvarez-Borrego, 2004). This photosynthetic activity is maintained in part by nutrient enrichment, including Cd (Álvarez-Molina, 2013; Delgadillo-Hinojosa et al., 2001). In this area, totoaba feed mainly on anchoveta Cetengraulis mysticetus and silverside Colpichthys spp (De Anda-Montañez et al., 2013), which in turn feed on plankton known to contain around $17 \mu \mathrm{g} \mathrm{g}^{-1} \mathrm{Cd}$ (Lane et al., 2005). The $\mathrm{Cd}$ assimilated by fish accumulates in the liver; in which it is bound mainly to metallothionein, a protein of low molecular weight with a high content of amino and sulfhydryl groups (Hamza-Chaffai et al., 1995). These proteins play a central role in the regulation and detoxification of trace elements. Divalent cations such as $\mathrm{Cd}$, have high affinity for sulfhydryl groups in metallothionein; as a result, $\mathrm{Cd}$ displaces essential elements such as $\mathrm{Zn}$, which upon release boost the synthesis of additional metallothionein (Bebianno \& Langston, 1991). The factors obtained by the PCA analysis showed that trace elements could be associated mainly to the reproductive physiology of the organisms as well as the starving/feeding conditions during the different seasons and in the different habitats. The reproduction process demands some metals that are required as co-factors of several enzymatic reactions involved in metabolic pathways (Olsson et al., 1987; Farkas et al., 2002; Canli \& Atl, 2003). The combined results from this study suggest that the observed variations in $\mathrm{Cd}, \mathrm{Cu}, \mathrm{Zn}$ and $\mathrm{Fe}$ concentrations in totoaba liver are related to the feeding and reproductive physiology of this species rather than to environmental exposure.

In this study, $\mathrm{Cu}, \mathrm{Cd}, \mathrm{Zn}, \mathrm{Fe}$, and $\mathrm{Pb}$ contents in totoaba muscle were within the ranges reported in fish from unpolluted areas of the Gulf of California (Ruelas-Inzunza et al., 2010). No 
401

402

403

404

405

406

407

408

409

410

411

412

413

414

415

416

417

418

419

420

421

422

423

424

425

426

427

428

429

430

431

432

433

434

435

436

437

438

439

440

441

442

443

444

significant variations in $\mathrm{Cu}$ and $\mathrm{Cd}$ content were observed in muscle neither significant loadings were obtained in the PCA indicating that the content of these elements in muscle is unaffected by season (potentially, migration) or by the maturity stage of the totoaba (Agah et al., 2009; Ruelas-Inzunza et al., 2010), In this study, in the factor 1 in the PCA, the content of $\mathrm{Zn}$ in muscle is associated especially with mature organisms in winter. Zinc is an essential component of metalloenzymes involved in the energy metabolism that contributes with muscle strength and resistance to fatigue (Krotkiewski et al., 1982).

In the PCA, in factor 2 the highest loadings of $\mathrm{Cd}_{\text {liver }}, \mathrm{Zn}_{\text {liver }}$ and $\mathrm{Fe}_{\text {liver }}$ that can be associated to the nutrition status of the totoaba, due to their starving/feeding periods, are also influenced by changes in their diet composition throughout the life cycle of these organisms (Farkas et al., 2002). Factor 3 could be associated with environmental conditions in the rocky and continental habitats that influence the Fe content in muscle of totoaba. All the HI obtained by MCS were $\mathrm{HI}<1$; this suggests a negligible health effect (Sanaei et al., 2020, USEPA, 1989) of $\mathrm{Cu}, \mathrm{Cd}, \mathrm{Zn}, \mathrm{Fe}$ or $\mathrm{Pb}$ content in muscle of totoaba consumed in human diet. The sensitivity analysis agrees with several previous studies reporting that the ingestion rate, rather than the concentration of the element in food, is more sensitive; therefore, small changes in the consumption rate would affect HI to a greater extent (Sanaei, et al., 2020; Chen et al., 2019; Guo et al., 2019).

Muscle $\mathrm{Cu}, \mathrm{Cd}, \mathrm{Zn}, \mathrm{Fe}$, and $\mathrm{Pb}$ concentrations were below the maximum permissible levels for human consumption established by the World Health Organization (WHO) and the European Community for seafood; i.e., $10 \mu \mathrm{g} \mathrm{g}^{-1} \mathrm{ww}$ for $\mathrm{Cu}$ (Australian legislation; (Nauen, 1983), $50 \mu \mathrm{g} \mathrm{g}^{-1} \mathrm{ww}$ for $\mathrm{Zn}$ (Collings et al., 1996), 0.05 and $0.2 \mu \mathrm{g} \mathrm{g}^{-1} \mathrm{ww}$ for $\mathrm{Cd}$ and $\mathrm{Pb}$, respectively (European Community, $(E C), 2005$; $(\mathrm{WHO}, 1996)$. Thus, consumption of totoaba does not pose a public health risk. Furthermore, depending on the sex/maturity stage of totoaba, consumption of this fish's muscle may provide approximately $70 \% \mathrm{Cu}, 60 \% \mathrm{Zn}$ and $100 \% \mathrm{Fe}$ of the recommended DRI. Both RDA and RfD are comparable to the values obtained in muscle of several fish species from the Mediterranean Sea and the Gulf de California (Bilandžić et al., 2014; Korkmaz et al., 2019; Zamora-Arellano et al., 2018). It is calculated that $130 \mathrm{~g}$ of totoaba muscle can provide approximately $20 \%$ of the daily tolerable dose of $\mathrm{Cd}$.

In a previous study, liver superoxide dismutase (SOD) activity was found to be related to totoaba's maturity stage (Hernández-Aguilar et al., 2018); thus, it was used in this study to further discriminate between environmental and physiologic effects on trace element content in totoaba. This third GLM explains 55\% of the variance and suggests that in liver, SOD activity is inversely related to $\mathrm{Cd}$ concentration in winter and spring $(p<0.05)$ but not in autumn $(p>$ 0.05). The GLMs constructed in this study suggest that liver Cd concentration varies inversely with liver $\mathrm{Zn}$ concentration, that liver $\mathrm{Cd}$ content affects muscle $\mathrm{Cd}$ concentrations, and that in the liver, SOD activity is inversely related to $\mathrm{Cd}$ concentration and length of the organisms. The totoaba collected in autumn have the highest liver Cd concentrations, and the highest SOD activity (Hernández-Aguilar et al., 2018). In autumn, immature and undifferentiated totoabas feed on sardines and crustaceans (Cisneros-Mata et al., 1995). In the Upper Gulf of California, in winter and spring, the feeding rate of totoaba is reduced as a result of the reproductive activity (Román Rodríguez \& Hammann, 1997). The liver is the primary organ where trace elements are stored and physiologically regulated in fish (Hamza-Chaffai et al., 1995; Roméo et al., 1999); it also participates in antioxidant defense mechanisms (including SOD) that protect tissues from 
445

446

447

448

449

450

451

452

453

454

455

456

457

458

459

460

461

462

463

464

465

466

467

468

469

470

471

472

473

474

475

476

477

478

479

480

481

482

483

484

485

the deleterious effects of free radicals (Basha \& Rani, 2003; Halliwell \& Gutteridge, 2007). In the present study, $\mathrm{Cd}$ content in totoaba liver may be indicative of the presence of this metal in the environment, but the content of $\mathrm{Cu}, \mathrm{Zn}$, and $\mathrm{Fe}$ may be associated primarily with the physiology of this fish rather than with the presence of these elements in the environment, as has been reported for other marine fish species (Hamza-Chaffai et al., 1995).

\section{Conclusions}

In summary, although totoaba migrates throughout the Gulf of California, where sites enriched by trace elements are common, $\mathrm{Cd}, \mathrm{Cu}, \mathrm{Zn}, \mathrm{Fe}$ and $\mathrm{Pb}$ content in liver and muscle of totoaba were within the levels considered as indicators of sites without contamination. Significantly higher $\mathrm{Cu}$ content in mature as compared to immature female totoaba was observed. The highest liver $\mathrm{Cd}$ concentrations were recorded at the time that totoaba are feeding around the large islands and the lowest Cd levels in liver were found during the reproductive stage. In muscle, significant variations were observed in $\mathrm{Zn}$ content associated with the maturity stage of the female totoaba. Therefore, variations in the content of $\mathrm{Cd}, \mathrm{Cu}, \mathrm{Zn}$ and $\mathrm{Fe}$ in liver of totoaba seem to be more related to the feeding and reproductive physiology of this species than as result of environmental exposure; further totoaba feeding ecology studies are suggested to confirm this. Results suggest that consumption of totoaba muscle does not pose a public health risk. Furthermore, depending on the sex/maturity stage of totoaba, this fish's muscle may provide approximately $70 \% \mathrm{Cu}, 60 \% \mathrm{Zn}$ and $100 \% \mathrm{Fe}$ of the recommended DRI.

\section{Acknowledgements}

Authors acknowledge L. Campos Dávila, J. J. Ramírez Rosas, N. O. Olguín Monroy, H. Bervera León, F. Valenzuela Quiñonez, O. U. Rodríguez García for their invaluable assistance in the field; B. Acosta Vargas and G. Peña Armenta for assistance with lab work; G. Hernández García and A. Landa Blanco for graphic art, and M. E. Sánchez-Salazar for edition of the English manuscript.

\section{References}

Agah, H., Leermakers, M., Elskens, M., Fatemi, S.M.R., Baeyens, W., 2009. Accumulation of trace metals in the muscle and liver tissues of five fish species from the Persian Gulf. Environ. Monit. Assess. 157, 499-514. https://doi.org/10.1007/s10661-008-0551-8

Álvarez-Molina, L., 2013. Annual and semiannual variations of phytoplankton biomass and production in the central Gulf of California estimated from satellite data. Cienc. Mar. 39, 217-230. https://doi.org/10.7773/cm.v39i2.2189

Arvizu Martínez, J., 1987. Fisheries activities in the Gulf of California, Mexico. Calif. Coop. Ocean. Fish. Investig. Reports 28, 32-36.

Arvizu J., Chávez, H., 1972 Sinopsis sobre la biología de la totoaba Cynoscion macdonaldi Gilbert, 1890. FAO Fish Biol. Synop. 108, 1-26.

Barrera-García, A., O’Hara, T., Galván-Magaña, F., Méndez-Rodríguez, L.C., Castellini, J.M., Zenteno-Savín, T., 2012. Oxidative stress indicators and trace elements in the blue shark 
(Prionace glauca) off the east coast of the Mexican Pacific Ocean. Comp. Biochem. Physiol. Part C Toxicol. Pharmacol. 156, 59-66. https://doi.org/10.1016/j.cbpc.2012.04.003 Basha, P.S., Rani, A.U., 2003. Cadmium-induced antioxidant defense mechanism in freshwater teleost Oreochromis mossambicus (Tilapia). Ecotoxicol. Environ. Saf. 56, 218-221. https://doi.org/10.1016/S0147-6513(03)00028-9

Bebianno, M.J., Langston, W.J., 1991. Metallothionein induction in Mytilus edulis exposed to cadmium. Mar. Biol. 108, 91-96. https://doi.org/10.1007/BF01313475

Bilandžić, N., Sedak, M., Đokić, M., Varenina, I., Solomun Kolanović, B., Božić, Đ., Brstilo, M., Šimić, B., 2014. Determination of zinc concentrations in foods of animal origin, fish and shellfish from Croatia and assessment of their contribution to dietary intake. J. Food Compos. Anal. 35, 61-66. https://doi.org/10.1016/j.jfca.2014.04.006

Burnham, K.P., Anderson, D.R. (Eds.), 2004. Model Selection and Multimodel Inference. Springer New York, New York, NY. https://doi.org/10.1007/b97636

Cadena-Cárdenas, L., Méndez-Rodríguez, L., Zenteno-Savín, T., García-Hernández, J., AcostaVargas, B., 2009. Heavy metal levels in marine mollusks from areas with, or without, mining activities along the Gulf of California, Mexico. Arch. Environ. Contam. Toxicol. 57, 96-102. https://doi.org/10.1007/s00244-008-9236-0

Canli, M., \& Atli, G. (2003). The relationships between heavy metal (Cd, Cr, Cu, Fe, Pb, Zn) levels and the size of six Mediterranean fish species. Environmental pollution, 121(1), 129136. https://doi.org/10.1016/S0269-7491(02)00194-X

Chen, G., Wang, X., Wang, R., \& Liu, G. (2019). Health risk assessment of potentially harmful elements in subsidence water bodies using a Monte Carlo approach: An example from the Huainan coal mining area, China. Ecotoxicology and Environmental Safety, 171, 737-745.

Cisneros-Mata, M.A., Botsford, L.W., Quinn, J.F., 1997. Projecting viability of Totoaba macdonaldi, a population with unknown age-dependent variability. Ecol. Appl. 7, 968-980.

Cisneros-Mata, M.A., Montemayor-Lopez, G., Roman-Rodriguez, M.J., 1995. Life History and Conservation of Totoaba macdonaldi. Conserv. Biol. 9, 806-814. https://doi.org/10.1046/j.1523-1739.1995.09040806.x

Collings, S.E., Johnson, M.S., Leah, R.T., 1996. Metal contamination of angler-caught fish from the Mersey Estuary. Mar. Environ. Res. 41, 281-297. https://doi.org/10.1016/01411136(95)00020-8

De Anda-Montañez, J.A., García de León, F.J., Zenteno-Savín, T., Balart-Paez, E., MéndezRodríguez, L. C., Bocanegra-Castillo, N., Martínez-Aguilar, S., Campos-Dávila, L., Román Rodríguez, M. J., Valenzuela-Quiñonez, F., Rodríguez-Jaramillo, M.E., Meza-Chávez, M.E., Ramírez-Rosas, J.J., Saldaña-Hernández, I.J., Olguín-Monroy, N.O., MartínezDelgado, M.E., 2013. Estado de salud y estatus de conservación de la(s) población(es) de totoaba (Totoaba macdonaldi) en el Golfo de California: una especie en peligro de extinción. Centro de Investigaciones Biológicas del Noroeste, S. C. La Paz, Baja California Sur. Informe Final, SNIB-CONABIO. Proyecto No. HK050, México, D.F. La Paz, Baja California Sur.

Delgadillo-Hinojosa, F., Macías-Zamora, J., Segovia-Zavala, J., Torres-Valdés, S., 2001. Cadmium enrichment in the Gulf of California. Mar. Chem. 75, 109-122. https://doi.org/10.1016/S0304-4203(01)00028-7

EC, 2005. European Community. Commission Regulation No 78/2005. Off. J. Eur. Union L16/43-L16/45.

EFSA. 2009. Cadmium in Food - Scientific Opinion of the Panel on Contaminants in the Food 
532

Chain. EFS2 2009, 7, doi:10.2903/j.efsa.2009.980.

EFSA. 2010. Scientific Opinion on Lead in Food. EFSA Journal 2010, doi:10.2903/j.efsa.2010.1570.

Farkas, A., Salanki, J., \& Specziar, A. (2002). Relation between growth and the heavy metal concentration in organs of bream Abramis brama L. populating Lake Balaton. Archives of environmental contamination and toxicology, 43(2), 236-243. https://doi.org/10.1007/s00244-002-1123-5

Flanagan, C.A., Hendrickson, J.R., 1976. Observations on the commercial fishery and reproductive biology of the totoaba Cynoscion macdonaldi in the northern Gulf of California Mexico. Fish. Bull. (washingt. D C) 74(3) 531-544 74, 531-544.

Findley, L. 2010. Totoaba macdonaldi. The IUCN Red List of Threatened Species 2010: e.T22003A9346099. http://dx.doi.org/10.2305/IUCN.UK.2010-3.RLTS.T22003A9346099

González-Reimers, E., Arnay-de-la-Rosa, M., Velasco-Vázquez, J., Galindo-Martín, L., Santolaria-Fernández, F., 2005. Bone cadmium and lead in the ancient population from El Hierro, Canary Islands. Biol. Trace Elem. Res. 105, 037-052. https://doi.org/10.1385/BTER:105:1-3:037

Guevara, J.C.B., 1990. The conservation of Totoaba macdonaldi (Gilbert), (Pisces: Sciaenidae), in the Gulf of California, Mexico. J. Fish Biol. 37, 201-202. https://doi.org/10.1111/j.1095$\underline{8649.1990 . t b 05038 . x}$

Guo, G., Zhang, D., \& Wang, Y. (2019). Probabilistic Human Health Risk Assessment of Heavy Metal Intake via Vegetable Consumption around $\mathrm{Pb} / \mathrm{Zn}$ Smelters in Southwest China. International journal of environmental research and public health, 16(18), 3267. https://doi.org/10.3390/ijerph16183267

Halliwell, B., Gutteridge, J.M.C., 2007. Free Radicals in Biology and Medicine, 4th ed. Oxford University Press, New York.

Hamza-Chaffai, A., Cosson, R.P., Amiard-Triquet, C., El Abed, A., 1995. Physico-chemical forms of storage of metals $(\mathrm{Cd}, \mathrm{Cu}$ and $\mathrm{Zn})$ and metallothionein-like proteins in gills and liver of marine fish from the Tunisian coast: ecotoxicological consequences. Comp. Biochem. Physiol. Part C Pharmacol. Toxicol. Endocrinol. 111, 329-341. https://doi.org/10.1016/0742-8413(95)00058-V

Han, S.; Auger, C.; Castonguay, Z.; Appanna, V.P.; Thomas, S.C.; Appanna, V.D. The Unravelling of Metabolic Dysfunctions Linked to Metal-Associated Diseases by Blue Native Polyacrylamide Gel Electrophoresis. Analytical and Bioanalytical Chemistry 2013, 405, 1821-1831.

Hernández-Aguilar, S.B., Zenteno-Savin, T., De-Anda-Montañez, J.A., Méndez-Rodríguez, L.C., 2018. Temporal variation in oxidative stress indicators in liver of totoaba (Totoaba macdonaldi) Perciformes: Sciaenidae. J. Mar. Biol. Assoc. United Kingdom 98. https://doi.org/10.1017/S0025315416001909

Hernández-Aguilar, Sandra Berenice, Zenteno-Savin, T., De-Anda-Montañez, J.A., MéndezRodríguez, L.C., 2018. Temporal variation in oxidative stress indicators in liver of totoaba (Totoaba macdonaldi) Perciformes: Sciaenidae. J. Mar. Biol. Assoc. United Kingdom 98, 833-844. https://doi.org/10.1017/S0025315416001909

Hidalgo-González, R.M., Alvarez-Borrego, S., 2004. Total and new production in the Gulf of California estimated from ocean color data from the satellite sensor SeaWIFS. Deep Sea Res. Part II Top. Stud. Oceanogr. 51, 739-752. https://doi.org/10.1016/j.dsr2.2004.05.006 Hobbs, N.T., Hilborn, R., 2006. Alternatives to statistical hypothesis testing in ecology: A guide 
578

to self teaching. Ecol. Appl. 16, 5-19. https://doi.org/10.1890/04-0645

Jara-Marini, M.E., Soto-Jiménez, M.F., Páez-Osuna, F., 2009. Trophic relationships and transference of cadmium, copper, lead and zinc in a subtropical coastal lagoon food web from SE Gulf of California. Chemosphere 77, 1366-1373. https://doi.org/10.1016/j.chemosphere.2009.09.025

Jia, Y., Wang, L., Li, S., Cao, J., \& Yang, Z. (2018). Species-specific bioaccumulation and correlated health risk of arsenic compounds in freshwater fish from a typical mine-impacted river. Science of the Total Environment, 625, 600-607. https://doi.org/10.1016/j.scitotenv.2017.12.328

Johnson, J.B., Omland, K.S., 2004. Model selection in ecology and evolution. Trends Ecol. Evol. 19, 101-108. https://doi.org/10.1016/j.tree.2003.10.013

Kalay, M., Ay, O., Canli, M., 1999. Heavy metal concentrations in fish tissues from the northeast Mediterranean Sea. Bull. Environ. Contam. Toxicol. 63, 673-681. https://doi.org/10.1007/s001289901033

Kalay, M., Canli, M., 2000. Elimination of essential (Cu, Zn) and non-essential (Cd, Pb) metals from tissues of a freshwater fish Tilapia zilli. Turkish J. Zool. 24, 429-436.

Kirchgessner, M., Roth, H.-P., Spoerl, R., Schnegg, A., Kellner, R.J., Weigand, E., 1977. A Comparative view on trace elements and growth. Ann. Nutr. Metab. 21, 119-143. https://doi.org/10.1159/000175758

Korkmaz, C., Ay, Ö., Ersoysal, Y., Köroğlu, M.A., Erdem, C., 2019. Heavy metal levels in muscle tissues of some fish species caught from north-east Mediterranean: Evaluation of their effects on human health. J. Food Compos. Anal. 81, 1-9. https://doi.org/10.1016/j.jfca.2019.04.005

Krotkiewski, M., Gudmundsson, M., Backström, P., \& Mandroukas, K. (1982). Zinc and muscle strength and endurance. Acta Physiologica Scandinavica, 116(3), 309-311. https://doi.org/10.1111/j.1748-1716.1982.tb07146.x

Lane, T.W., Saito, M.A., George, G.N., Pickering, I.J., Prince, R.C., Morel, F.M.M., 2005. A cadmium enzyme from a marine diatom. Nature 435, 42-42. https://doi.org/10.1038/435042a

Mathews, T., Fisher, N. S., 2009. Dominance of dietary intake of metals in marine elasmobranch and teleost fish. Sci. Total Environ. 407, 5156-5161. http://dx.doi.org/10.1016/j.scitotenv.2009.06.003

Manea, D.N.; Ienciu, A.A.; Ştef, R.; Şmuleac, I.L.; Gergen, I.I.; Nica, D.V. Health Risk Assessment of Dietary Heavy Metals Intake from Fruits and Vegetables Grown in Selected Old Mining Areas-A Case Study: The Banat Area of Southern Carpathians. International Journal of Environmental Research and Public Health 2020, 17, 5172, doi:10.3390/ijerph17145172.

Monikh, F., Peery, S., Karami, O., Hosseini, M., Bastami, A.A., Ghasemi, A.F., 2012. Distribution of metals in the tissues of benthic, Euryglossa orientalis and Cynoglossus arel., and bentho-pelagic, Johnius belangerii., fish from three estuaries, Persian Gulf. Bull. Environ. Contam. Toxicol. 89, 489-494. https://doi.org/10.1007/s00128-012-0747-z Murillo-Cisneros, D.A., O’Hara, T.M., Castellini, J.M., Sánchez-González, A., ElorriagaVerplancken, F.R., Marmolejo-Rodríguez, A.J., Marín-Enríquez, E., Galván-Magaña, F., 2018. Mercury concentrations in three ray species from the Pacific coast of Baja California Sur, Mexico: Variations by tissue type, sex and length. Mar. Pollut. Bull. 126, 77-85. https://doi.org/10.1016/j.marpolbul.2017.10.060 
624

625

626

627

628

629

630

631

632

633

634

635

636

637

638

639

640

641

642

643

644

645

646

647

648

649

650

651

652

653

654

655

656

657

658

659

660

661

662

663

664

665

666

667

668

669

National Academies of Sciences, Engineering, and Medicine, 2017. Guiding Principles for Developing Dietary Reference Intakes Based on Chronic Disease. National Academies Press, Washington, D.C. https://doi.org/10.17226/24828

Nauen, C.E., 1983. Compilation of legal limits for hazardous substances in fish and fishery products. FAO Fisheries Circular, Rome.

O'Shea, T.J., Brownell, R.L., 1994. Organochlorine and metal contaminants in baleen whales: a review and evaluation of conservation implications. Sci. Total Environ. 154, 179-200. https://doi.org/10.1016/0048-9697(94)90087-6

Olsson, P.-E., Haux, C., Förlin, L., 1987. Variations in hepatic metallothionen, zinc and copper levels during an annual reproductive cycle in rainbow trout, Salmo gairdneri. Fish Physiol. Biochem. 3, 39-47. https://doi.org/10.1007/BF02183992

Page, L., Espinosa-Pérez, H., Findley, L. T., Gilbert, C. R., Lea, R. N., Mandrak, N. E., Mayden, R. L., Nelson, J. S., 2013. Common and scientific names of fishes from the United States, Canada, and Mexico. $7^{\text {th }}$ ed. American Fishery Society, Spec. Publ. 34, Bethesda, Maryland. https://doi.org/10.1080/03632415.2013.767244

Parihar, M.S., Dubey, A.K., 1995. Lipid peroxidation and ascorbic acid status in respiratory organs of male and female freshwater catfish Heteropneustes fossilis exposed to temperature increase. Comp. Biochem. Physiol. Part C Pharmacol. Toxicol. Endocrinol. 112, 309-313. https://doi.org/10.1016/0742-8413(95)02025-X

Parihar, M.S., Javeri, T., Hemnani, T., Dubey, A.K., Prakash, P., 1997. Responses of superoxide dismutase, glutathione peroxidase and reduced glutathione antioxidant defenses in gills of the freshwater catfish (Heteropneustes fossilis) to short-term elevated temperature. J. Therm. Biol. 22, 151-156. https://doi.org/10.1016/S0306-4565(97)00006-5

Román Rodríguez, M.J., Hammann, M.G., 1997. Age and growth of totoaba, Totoaba macdonaldi (Sciaenidae), in the upper Gulf of California. Fish. Bull. 95, 620-628.

Roméo, M., Siau, Y., Sidoumou, Z., Gnassia-Barelli, M., 1999. Heavy metal distribution in different fish species from the Mauritania coast. Sci. Total Environ. 232, 169-175. https://doi.org/10.1016/S0048-9697(99)00099-6

Rudneva, I.I., 1997. Blood antioxidant system of Black Sea elasmobranch and teleosts. Comp. Biochem. Physiol. Part C Pharmacol. Toxicol. Endocrinol. 118, 255-260. https://doi.org/10.1016/S0742-8413(97)00111-4

Rudneva, I.I., Skuratovskaya, E.N., 2009. Gender peculiarities of blood antioxidant enzyme activity of some Black Sea coastal fish species. J. Ichthyol. 49, 119-122. https://doi.org/10.1134/S0032945209010159

Rueda-López, S., Lazo, J.P., Reyes, G.C., Viana, M.T., 2011. Effect of dietary protein and energy levels on growth, survival and body composition of juvenile Totoaba macdonaldi. Aquaculture 319, 385-390. https://doi.org/10.1016/j.aquaculture.2011.07.007

Ruelas-Inzunza, J., Páez-Osuna, F., 2008. Trophic distribution of Cd, Pb, and $\mathrm{Zn}$ in a food web from Altata-Ensenada del Pabellón subtropical lagoon, SE Gulf of California. Arch. Environ. Contam. Toxicol. 54, 584-596. https://doi.org/10.1007/s00244-007-9075-4

Ruelas-Inzunza, J., Páez-Osuna, F., García-Flores, D., 2010. Essential (Cu) and nonessential (Cd and $\mathrm{Pb}$ ) metals in ichthyofauna from the coasts of Sinaloa state (SE Gulf of California). Environ. Monit. Assess. 162, 251-263. https://doi.org/10.1007/s10661-009-0793-0

Sanaei, F., Amin, M. M., Alavijeh, Z. P., Esfahani, R. A., Sadeghi, M., Bandarrig, N. S., ... \& Rezakazemi, M. (2020). Health risk assessment of potentially toxic elements intake via food crops consumption: Monte Carlo simulation-based probabilistic and heavy metal pollution

Peer) reviewing PDF | (2020:10:53478:2:0:NEW 10 Feb 2021) 
670

index. Environmental Science and Pollution Research, 1-12. Doi:

https://doi.org/10.1007/s11356-020-10450-7

Shumilin, E., Páez-osuna, F., Green-ruiz, C., Sapozhnikov, D., Rodríguez-meza, G.D., Godínezorta, L., 2001. Arsenic, antimony, selenium and other trace elements in sediments of the La Paz lagoon, Peninsula of Baja California, Mexico. Mar. Pollut. Bull. 42, 174-178. https://doi.org/10.1016/S0025-326X(00)00123-5

Shumilin, E.N., Rodríguez-Figueroa, G., Bermea, O.M., Baturina, E.L., Hernández, E., Meza, G.D.R., 2000. Anomalous trace element composition of coastal sediments near the copper mining district of Santa Rosalía, Peninsula of Baja California, Mexico. Bull. Environ. Contam. Toxicol. 65, 261-268. https://doi.org/10.1007/s001280000123

Thompson, E.D., Mayer, G.D., Walsh, P.J., Hogstrand, C., 2002. Sexual maturation and reproductive zinc physiology in the female squirrelfish. J. Exp. Biol. 205, 3367-3376.

Thompson, E.D., Olsson, P.-E., Mayer, G.D., Haux, C., Walsh, P.J., Burge, E., Hogstrand, C., 2001. Effects of 17 $\beta$-estradiol on levels and distribution of metallothionein and zinc in squirrelfish. Am. J. Physiol. Integr. Comp. Physiol. 280, R527-R535. https://doi.org/10.1152/ajpregu.2001.280.2.R527 True, C.D., Silva Loera, A., Castro Castro, N., 1997. Technical Notes: Acquisition of broodstock of Totoaba macdonaldi: Field handling, decompression, and prophylaxis of an endangered species. Progress. FishCulturist 59, 246-248. https://doi.org/10.1577/1548-8640(1497)059

Trumbo, P., Yates, A. A., Schlicker, S., \& Poos, M. (2001). Dietary reference intakes: vitamin A, vitamin $\mathrm{K}$, arsenic, boron, chromium, copper, iodine, iron, manganese, molybdenum, nickel, silicon, vanadium, and zinc. Journal of the Academy of Nutrition and Dietetics, 101(3), 294. doi: 10.1016/S0002-8223(01)00078-5

Tyler, C.R., Sumpter, J.P., 1996. Oocyte growth and development in teleosts. Rev. Fish Biol. Fish. 6, 287-318. https://doi.org/10.1007/BF00122584

Viana, F., Huertas, R., Danulat, E., 2005. Heavy metal levels in fish from coastal waters of Uruguay. Arch. Environ. Contam. Toxicol. 48, 530-537. https://doi.org/10.1007/s00244004-0100-6

WHO, 1996. Zinc. In: Trace elements in human nutrition and health., World Health Organization, Geneva, Switzerland. World Health Organization, Geneva.

Zamora-Arellano, N., Betancourt-Lozano, M., Ilizaliturri-Hernández, C., García-Hernández, J., Jara-Marini, M., Chávez-Sánchez, C., Ruelas-Inzunza, J.R., 2018. Mercury levels and risk implications through fish consumption on the Sinaloa coasts (Gulf of California, Northwest Mexico). Risk Anal. 38, 2646-2658. https://doi.org/10.1111/risa.13185

Zar, J.H., 1998. Biostatistical Analysis, 4th ed. Prentice Hall, Upper Saddle River, New Jersey. Zuur, A., Ieno, E.N., Walker, N., Saveliev, A.A., Smith, G.M., 2009. Mixed Effects Models and Extensions in Ecology with R. Springer New York, New York, NY. 


\section{Table 1 (on next page)}

Monte Carlo parameter distributions and parameters used in the health risk assessment.

$\mathrm{EDI}=$ estimated daily intake; $\mathrm{Bw}=$ body weight; $\mathrm{CR}=$ consumption rate; $\mathrm{HI}=$ hazard index;

$\mathrm{C}_{\text {metal }}=$ metal concentration in muscle of totoaba; $\mathrm{RfD}=$ reference dosis 


\begin{tabular}{|c|c|c|c|c|c|}
\hline Parameters & Unit & Description & Distribution & Value & Ref \\
\hline EDI & $\begin{array}{l}\left(\mathrm{mg} \mathrm{kg} \mathrm{kg}^{-1}\right) \\
\text { day }^{-1}\end{array}$ & $\begin{array}{l}\text { Estimated Daily } \\
\text { Intake through } \\
\text { ingestion }\end{array}$ & - & Equation 1 & Bilandžić et al., 2014 \\
\hline $\mathrm{Bw}$ & $\mathrm{Kg}$ & Body weight adult & Log normal & $74 \pm 10 \mathrm{~kg}$ & $\begin{array}{l}\text { Zamora-Arellano et al., } \\
2018\end{array}$ \\
\hline $\mathrm{CR}$ & $\mathrm{Kg}_{\text {day }}{ }^{-1}$ & Consumption Rate & Log normal & $0.100 \pm 0.030$ & $\begin{array}{l}\text { Zamora-Arellano et al., } \\
2018\end{array}$ \\
\hline HI & & Hazard Index & - & & Sanaei et al. 2020 \\
\hline $\mathrm{C}_{\text {metal }}$ & $\mathrm{mg} \mathrm{kg}^{-1}$ & & Log normal & & \\
\hline RfD & $\begin{array}{l}\left(\mathrm{mg} \mathrm{kg}^{-1}\right) \\
\text { day }^{-1}\end{array}$ & $\begin{array}{l}\text { Reference dose of } \\
\text { heavy metals }\end{array}$ & $\begin{array}{l}\text { Fixed } \\
\text { values }\end{array}$ & $\begin{array}{l}\text { Varied depending on } \\
\text { the specific metal }\end{array}$ & $\begin{array}{l}\text { USEPA, 2020; Chen et al. } \\
2029\end{array}$ \\
\hline
\end{tabular}




\section{Table 2 (on next page)}

Factors hypothesized to affect cadmium (Cd) in liver and muscle of totoaba (Totoaba macdonaldi) sampled in the Gulf of California, Mexico. 


\begin{tabular}{ccc}
\hline Variable & Type & Description \\
\hline Season & Categorical & Autumn \\
& & Winter \\
& & Spring \\
Sex/maturity stage & Categorical & MF; mature females \\
& & MM; mature males \\
& & IF; immature females \\
Length & & IM; immature males \\
Cadmium in liver and muscle & Continuous & Metal concentration $\left(\mu \mathrm{g} \cdot \mathrm{g}^{-1}\right)$ \\
Copper in liver and muscle & Continuous & Metal concentration $\left(\mu \mathrm{g} \cdot \mathrm{g}^{-1}\right)$ \\
Zinc in liver and muscle & Continuous & Metal concentration $\left(\mu \mathrm{g} \cdot \mathrm{g}^{-1}\right)$ \\
Iron in liver and muscle & Continuous & Metal concentration $\left(\mu \mathrm{g} \cdot \mathrm{g}^{-1}\right)$
\end{tabular}




\section{Table 3 (on next page)}

Trace elements concentration $\left(\mu \mathrm{g} \cdot \mathrm{g}^{-1}\right)$ in liver and muscle of Totoaba macdonaldi by season and sex/maturity stage groups.

Totoaba groups: MF, mature females; MM, mature males; IF, immature females; IM, immature males; UN, undifferentiated. Different letters indicate significant differences $(p<0.05)$; lowercase letters denote differences within a habitat and season between maturity stages for each sex in liver; uppercase letters denote differences within a habitat and season between maturity stages for each sex in muscle. $\mathrm{E}=$ estuarine; $\mathrm{R}=$ rocky; $\mathrm{C}=$ continental. Values are shown as means \pm standard error. 
1

\begin{tabular}{|c|c|c|c|c|c|c|c|c|c|}
\hline Tissue & Habitat & $\mathbf{n}$ & Season & $\begin{array}{l}\text { Sex/maturity } \\
\text { Stage }\end{array}$ & Copper & Cadmium & Zinc & Iron & Lead \\
\hline \multicolumn{10}{|l|}{ Liver } \\
\hline & & Winter & & & & & & & \\
\hline & $\mathrm{E}$ & 15 & & MF & $44.04 \pm 5.02^{\mathrm{a}}$ & $1.82 \pm 0.30^{\mathrm{a}}$ & $116.13 \pm 6.26^{\mathrm{a}}$ & $1,284 \pm 103^{\mathrm{abcd}}$ & $<0.07$ \\
\hline & $\mathrm{E}$ & 18 & & $\mathrm{MM}$ & $35.84 \pm 2.39^{\mathrm{ab}}$ & $3.18 \pm 1.13^{\mathrm{abc}}$ & $107.98 \pm 4.14$ ab & $1,187 \pm 151^{\mathrm{abcd}}$ & $<0.07$ \\
\hline & & Spring & & & & & & & \\
\hline & $\mathrm{E}$ & 8 & & MF & $36.02 \pm 8.05^{\mathrm{ab}}$ & $0.89 \pm 0.38^{\mathrm{a}}$ & $80.68 \pm 6.81 \mathrm{ab}$ & $623 \pm 137$ ab & $<0.07$ \\
\hline & $\mathrm{E}$ & 3 & & $\mathrm{MM}$ & $22.78 \pm 5.83^{a b}$ & $0.89 \pm 0.73^{a b}$ & $72.26 \pm 6.58^{\mathrm{ab}}$ & $628 \pm 46^{\mathrm{abcd}}$ & $<0.07$ \\
\hline & $\mathrm{R}$ & 7 & & MF & $24.23 \pm 2.20^{a b}$ & $1.64 \pm 0.89 \mathrm{ab}$ & $69.41 \pm 1.52^{b}$ & $556 \pm 93^{\text {a }}$ & $<0.07$ \\
\hline & $\mathrm{R}$ & 8 & & $\mathrm{MM}$ & $20.07 \pm 4.43^{b}$ & $1.24 \pm 0.37 \mathrm{ab}$ & $79.86 \pm 6.29 \mathrm{ab}$ & $813 \pm 173^{\mathrm{abd}}$ & $<0.07$ \\
\hline & $\mathrm{R}$ & 11 & & IF & $21.80 \pm 3.34^{b}$ & $0.47 \pm 0.36^{\mathrm{a}}$ & $86.66 \pm 5.95^{\mathrm{ab}}$ & $560 \pm 59^{a b}$ & $<0.07$ \\
\hline & $\mathrm{R}$ & 6 & & $\mathrm{IM}$ & $23.40 \pm 6.21^{\mathrm{ab}}$ & $1.06 \pm 0.70^{a b}$ & $76.55 \pm 11.15^{\mathrm{ab}}$ & $787 \pm 283 \mathrm{abc}$ & $<0.07$ \\
\hline & & Autumn & & & & & & & \\
\hline & $\mathrm{R}$ & 12 & & IF & $28.87 \pm 4.02^{\mathrm{ab}}$ & $5.53 \pm 0.96^{\mathrm{c}}$ & $93.89 \pm 11.70^{\mathrm{ab}}$ & $1,521 \pm 189^{\mathrm{bcd}}$ & $<0.07$ \\
\hline & $\mathrm{R}$ & 11 & & IM & $31.34 \pm 4.32^{\mathrm{ab}}$ & $6.7 \pm 1.01^{\mathrm{c}}$ & $97.82 \pm 10.29^{\mathrm{ab}}$ & $1961 \pm 336^{\mathrm{d}}$ & $<0.07$ \\
\hline & $\mathrm{R}$ & 21 & & UN & $25.89 \pm 2.96^{\mathrm{b}}$ & $5.33 \pm 0.61^{\mathrm{c}}$ & $96.00 \pm 5.34^{\mathrm{ab}}$ & $1,792 \pm 181^{\mathrm{cd}}$ & $<0.07$ \\
\hline & $\mathrm{C}$ & 9 & & IF & $16.30 \pm 2.93^{b}$ & $1.32 \pm 0.22^{\mathrm{a}}$ & $89.58 \pm 8.37^{\mathrm{ab}}$ & $400 \pm 63^{a}$ & $<0.07$ \\
\hline & $\mathrm{C}$ & 7 & & IM & $11.80 \pm 2.64^{\mathrm{b}}$ & $1.06 \pm 0.09 \mathrm{ab}$ & $75.74 \pm 4.26^{\mathrm{ab}}$ & $359 \pm 49^{\mathrm{a}}$ & $<0.07$ \\
\hline & $\mathrm{C}$ & 6 & & UN & $20.90 \pm 4.58^{b}$ & $2.38 \pm 0.50 \mathrm{abc}$ & $113.62 \pm 12.84^{a b}$ & $470 \pm 92^{\mathrm{ab}}$ & $<0.07$ \\
\hline Muscl & & & & & & & & & \\
\hline
\end{tabular}




\begin{tabular}{|c|c|c|c|c|c|c|c|}
\hline \multicolumn{8}{|c|}{ Winter } \\
\hline $\mathbf{E}$ & 14 & MF & $1.80 \pm 0.41$ & $<0.01$ & $17.74 \pm 1.00^{\mathrm{A}}$ & $22.99 \pm 2.84 \mathrm{ABC}$ & $<0.07$ \\
\hline $\mathbf{E}$ & 18 & MM & $1.54 \pm 0.32$ & $<0.01$ & $17.78 \pm 0.72^{\mathrm{A}}$ & $20.43 \pm 4.00 \mathrm{ABC}$ & $<0.07$ \\
\hline \multicolumn{8}{|c|}{ Spring } \\
\hline $\mathbf{E}$ & 8 & MF & $0.86 \pm 0.43$ & $<0.01$ & $15.15 \pm 0.61^{\mathrm{AB}}$ & $21.67 \pm 1.95^{\mathrm{ABC}}$ & $<0.07$ \\
\hline $\mathbf{E}$ & 3 & MM & $1.01 \pm 0.54$ & $<0.01$ & $15.73 \pm 1.78^{\mathrm{AB}}$ & $22.49 \pm 3.63 \mathrm{ABC}$ & $<0.07$ \\
\hline $\mathbf{R}$ & 7 & $\mathrm{MF}$ & $2.00 \pm 0.80$ & $0.03 \pm 0.02$ & $13.86 \pm 3.20^{\mathrm{AB}}$ & $21.90 \pm 5.88 \mathrm{ABC}$ & $<0.07$ \\
\hline $\mathbf{R}$ & 8 & MM & $0.39 \pm 0.19$ & $<0.01$ & $11.79 \pm 1.16^{\mathrm{B}}$ & $12.74 \pm 1.55^{\mathrm{ABC}}$ & $<0.07$ \\
\hline $\mathbf{R}$ & 12 & IF & $<0.017$ & $<0.01$ & $12.42 \pm 0.42^{\mathrm{B}}$ & $11.73 \pm 2.13 \mathrm{AB}$ & $<0.07$ \\
\hline $\mathbf{R}$ & 6 & $\mathrm{IM}$ & $0.32 \pm 0.21$ & $<0.01$ & $13.84 \pm 0.49 \mathrm{AB}$ & $21.90 \pm 4.47 \mathrm{ABC}$ & $<0.07$ \\
\hline \multicolumn{8}{|c|}{ Autumn } \\
\hline $\mathbf{R}$ & 12 & IF & $0.48 \pm 0.19$ & $<0.01$ & $12.23 \pm 1.44^{\mathrm{B}}$ & $7.96 \pm 2.73^{\mathrm{B}}$ & $<0.07$ \\
\hline $\mathbf{R}$ & 11 & $\mathrm{IM}$ & $1.68 \pm 1.06$ & $<0.01$ & $11.91 \pm 1.04^{\mathrm{B}}$ & $15.03 \pm 4.79^{\mathrm{ABC}}$ & $<0.07$ \\
\hline $\mathbf{R}$ & 21 & UN & $0.04 \pm 0.02$ & $<0.01$ & $11.74 \pm 0.59^{\mathrm{B}}$ & $10.84 \pm 2.54 \mathrm{AB}$ & $<0.07$ \\
\hline C & 9 & IF & $1.37 \pm 0.62$ & $<0.01$ & $11.35 \pm 0.65^{\mathrm{B}}$ & $18.18 \pm 1.58^{\mathrm{ABC}}$ & $<0.07$ \\
\hline $\mathbf{C}$ & 8 & IM & $0.48 \pm 0.35$ & $<0.01$ & $10.95 \pm 0.50^{\mathrm{B}}$ & $33.17 \pm 6.50^{\mathrm{C}}$ & $<0.07$ \\
\hline $\mathbf{C}$ & 7 & UN & $0.69 \pm 0.46$ & $0.15 \pm 0.14$ & $13.07 \pm 0.66^{\mathrm{AB}}$ & $31.19 \pm 5.36^{\mathrm{AC}}$ & $<0.07$ \\
\hline
\end{tabular}

2 


\section{Table 4 (on next page)}

Sensitivity analyses of input parameters for the effect in the hazard index (HI) as estimation of the health risk for consumption of muscle of totoaba. The level of sensitivity is shown as contribution to the variance (\%) and rank correlation $(10,000$ tria 


\begin{tabular}{|c|c|c|c|}
\hline & Parameters & $\begin{array}{l}\text { Contribution to Variance } \\
\text { (\%) }\end{array}$ & $\begin{array}{l}\text { Rank } \\
\text { correlation }\end{array}$ \\
\hline \multirow[t]{3}{*}{ Sensitivity: $\mathrm{HI}_{\text {copper }}$} & $\begin{array}{l}\text { Consumption } \\
\text { Rate }\end{array}$ & 7.54E-01 & 8.53E-01 \\
\hline & Body weight & $1.60 \mathrm{E}-01$ & $-3.92 E-01$ \\
\hline & Copper muscle & $8.56 \mathrm{E}-02$ & $2.87 \mathrm{E}-01$ \\
\hline Sensitivity: & Consumption & 8.27E-01 & $8.98 \mathrm{E}-01$ \\
\hline \multirow[t]{3}{*}{$\mathrm{HI}_{\text {cadmium }}$} & Rate & & \\
\hline & Body weight & $1.72 \mathrm{E}-01$ & $-4.10 \mathrm{E}-01$ \\
\hline & Cadmium muscle & $1.34 \mathrm{E}-05$ & $3.62 \mathrm{E}-03$ \\
\hline \multirow[t]{3}{*}{ Sensitivity: $\mathrm{HI}_{\text {zinc }}$} & $\begin{array}{l}\text { Consumption } \\
\text { Rate }\end{array}$ & 8.27E-01 & $8.98 \mathrm{E}-01$ \\
\hline & Body weight & $1.72 \mathrm{E}-01$ & $-4.10 \mathrm{E}-01$ \\
\hline & Zinc $_{\text {muscle }}$ & $1.74 \mathrm{E}-05$ & $4.12 \mathrm{E}-03$ \\
\hline \multirow[t]{4}{*}{ Sensitivity: $\mathrm{HI}_{\text {iron }}$} & Consumption & $8.30 \mathrm{E}-01$ & $9.01 \mathrm{E}-01$ \\
\hline & Rate & & \\
\hline & Body weight & $1.70 \mathrm{E}-01$ & $-4.07 E-01$ \\
\hline & Iron muscle & $6.95 \mathrm{E}-05$ & $8.24 \mathrm{E}-03$ \\
\hline
\end{tabular}




\section{Table 5 (on next page)}

Loadings for season (winter, spring and autumn), habitat (estuarine, rocky, continental), sex/maturity stage (male, female, mature, immature, undifferentiated) and estimated dairy intake (EDI) of trace metal content in muscle in totoaba on VARIMAX-rotated 


\begin{tabular}{|c|c|c|c|}
\hline Variable & Factor 1 & Factor 2 & Factor 3 \\
\hline Winter & $-0.864 *$ & 0.201 & 0.114 \\
\hline Spring & $0.726^{*}$ & 0.496 & 0.380 \\
\hline Autumn & 0.001 & $-0.724 *$ & -0.518 \\
\hline Estuarine & $-0.932 *$ & -0.002 & 0.049 \\
\hline Rocky & 0.632 & 0.074 & $-0.664 *$ \\
\hline Continental & 0.316 & -0.099 & $0.848 *$ \\
\hline Mature females & $-0.541 *$ & -0.219 & -0.095 \\
\hline Mature male & $-0.505^{*}$ & -0.084 & -0.112 \\
\hline Immature females & $0.389 *$ & -0.146 & -0.040 \\
\hline Immature males & $0.294 *$ & 0.006 & 0.146 \\
\hline Undifferentiated & 0.401 & $0.445^{*}$ & 0.144 \\
\hline
\end{tabular}




\begin{tabular}{|c|c|c|c|}
\hline Copper $_{\text {muscle }}$ & $-0.332 *$ & -0.111 & 0.225 \\
\hline Cadmium $_{\text {muscle }}$ & 0.069 & 0.018 & $0.251 *$ \\
\hline Zinc $_{\text {muscle }}$ & $-0.700 *$ & 0.100 & 0.070 \\
\hline Iron $_{\text {muscle }}$ & -0.281 & -0.206 & $0.524 *$ \\
\hline Copper ${ }_{\text {liver }}$ & $-0.511^{*}$ & 0.434 & -0.248 \\
\hline Cadmium $_{\text {liver }}$ & 0.149 & $0.788^{*}$ & -0.224 \\
\hline Zinc $_{\text {liver }}$ & -0.322 & $0.663^{*}$ & -0.006 \\
\hline Iron $_{\text {liver }}$ & -0.011 & $0.780 *$ & -0.318 \\
\hline Eigenvalue & 4.67 & 3.02 & 2.24 \\
\hline Explained variance (\%) & 24.60 & 15.88 & 11.81 \\
\hline Cumulative variance & 24.60 & 40.48 & 52.28 \\
\hline
\end{tabular}

2 


\section{Table 6(on next page)}

Generalized linear models explaining the variability of cadmium (Cd) in liver and muscle of Totoaba macdonaldi. Values marked with * were significantly different $(p<0.05)$ from the intercept.

MF, mature females; MM, mature males; IM, immature males; IF, immature females; ${ }^{a}$ Akaike information criterion, ${ }^{\mathrm{b} B a y e s i a n}$ information criterion; s. e., standard error. 


\begin{tabular}{|c|c|c|c|c|}
\hline \multirow[b]{2}{*}{ Statistics } & \multicolumn{4}{|c|}{ Models } \\
\hline & \multicolumn{2}{|c|}{ 1; Cd in liver } & \multicolumn{2}{|c|}{ 2; Cd in muscle } \\
\hline Error & \multicolumn{2}{|c|}{ Gamma } & \multicolumn{2}{|c|}{ Gamma } \\
\hline Link & \multicolumn{2}{|c|}{$\log$} & \multicolumn{2}{|c|}{$\log$} \\
\hline Deviance & \multicolumn{2}{|c|}{172} & \multicolumn{2}{|c|}{73} \\
\hline Explained deviance & \multicolumn{2}{|c|}{$46 \%$} & \multicolumn{2}{|c|}{$71 \%$} \\
\hline Pearson $\mathrm{Chi}^{2}$ & \multicolumn{2}{|c|}{103} & \multicolumn{2}{|c|}{76} \\
\hline Log likelihood & \multicolumn{2}{|c|}{-167} & \multicolumn{2}{|c|}{505} \\
\hline Df & \multicolumn{2}{|c|}{100} & \multicolumn{2}{|c|}{74} \\
\hline Deviance/Df & \multicolumn{2}{|c|}{1.72} & \multicolumn{2}{|c|}{0.98} \\
\hline Pearson's $\mathrm{Chi}^{2} / \mathrm{Df}$ & \multicolumn{2}{|c|}{1.03} & \multicolumn{2}{|c|}{1.03} \\
\hline Level of Effect & Estimate & s. e. & Estimate & s. e. \\
\hline Intercept & $-4.04 *$ & 0.92 & $-5.93 *$ & 0.73 \\
\hline Copper in muscle & -0.06 & 0.08 & -0.07 & 0.06 \\
\hline Cadmium in muscle & 0.70 & 1.18 & -- & -- \\
\hline Zinc in muscle & -0.02 & 0.03 & -0.04 & 0.03 \\
\hline Iron in muscle & 0.004 & 0.01 & 0.01 & 0.008 \\
\hline Length & $0.00006^{*}$ & 0.00002 & 0.00002 & 0.46 \\
\hline Copper in liver & 0.02 & 0.009 & -0.008 & 0.007 \\
\hline Cadmium in liver & -- & -- & $0.14 *$ & 0.05 \\
\hline Zinc in liver & $0.01 *$ & 0.006 & -0.001 & 0.005 \\
\hline Iron in liver & 0.0003 & 0.0002 & 0.0001 & 0.0002 \\
\hline Season 1 (winter) & $-2.98 *$ & 0.58 & 0.33 & 0.40 \\
\hline Season 2 (spring) & 0.31 & 0.45 & 0.14 & 0.24 \\
\hline Sex/maturity stage (MF) & $1.28 *$ & 0.49 & $2.16^{*}$ & 0.44 \\
\hline Sex/maturity stage (MM) & $1.79 *$ & 0.41 & $1.08 *$ & 0.37 \\
\hline Sex/maturity stage (IM) & 0.45 & 0.70 & $1.35^{*}$ & 0.45 \\
\hline Sex/maturity stage (IF) & $0.83 *$ & 0.39 & $-1.18 *$ & 0.27 \\
\hline Season $1 *$ Sex/maturity stage & $3.50 *$ & 0.95 & $2.21^{*}$ & 0.58 \\
\hline Season $2 *$ Sex/maturity stage & $1.88^{*}$ & 0.96 & -- & -- \\
\hline $\mathrm{AIC}^{\mathrm{a}}$ & \multicolumn{2}{|c|}{386} & \multicolumn{2}{|c|}{-964} \\
\hline $\mathrm{BIC}^{\mathrm{b}}$ & \multicolumn{2}{|c|}{459} & \multicolumn{2}{|c|}{-905} \\
\hline
\end{tabular}

2 
Figure 1

Totoaba macdonaldi study area in the Gulf of California. 


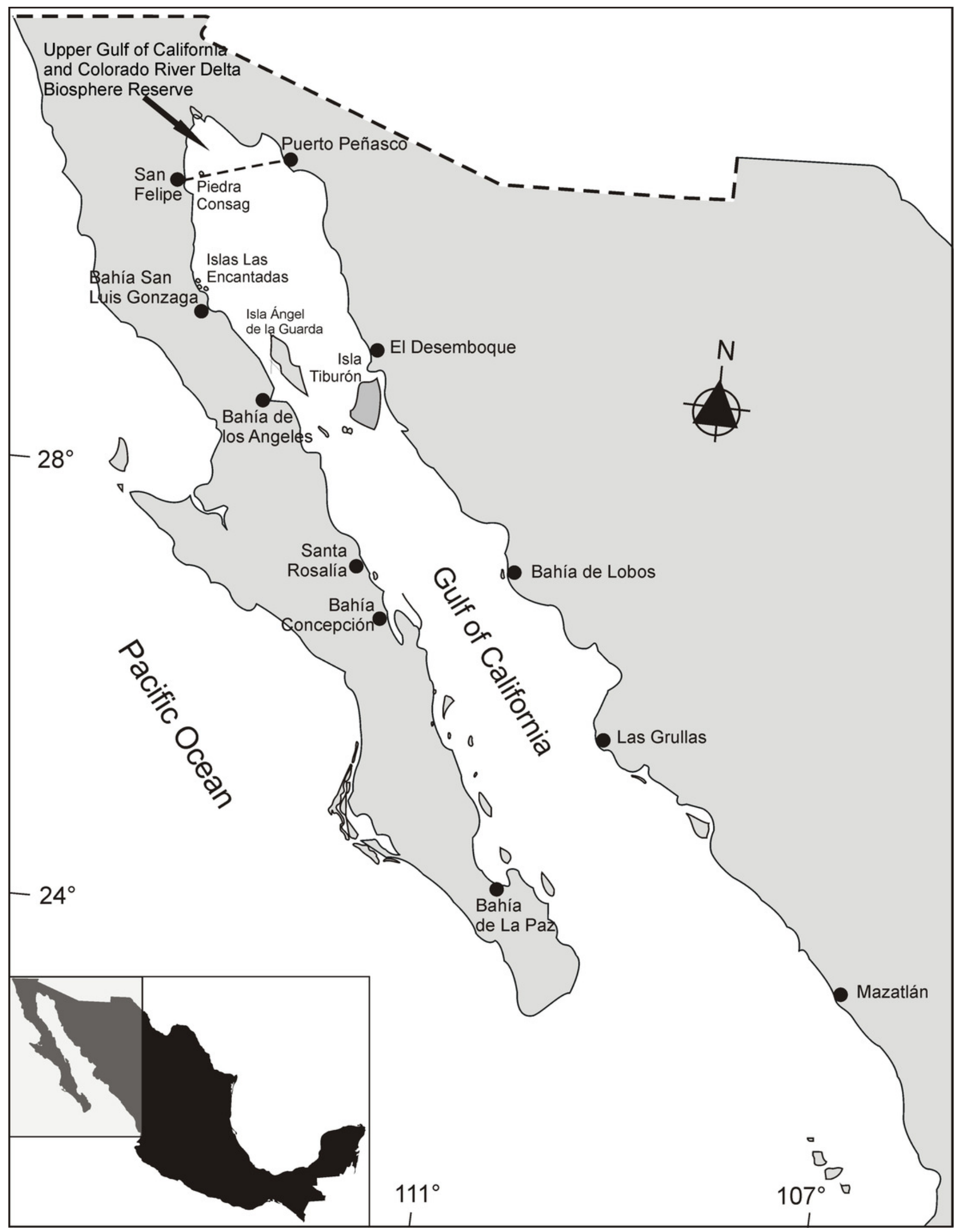


Figure 2

Overview of experimental program.

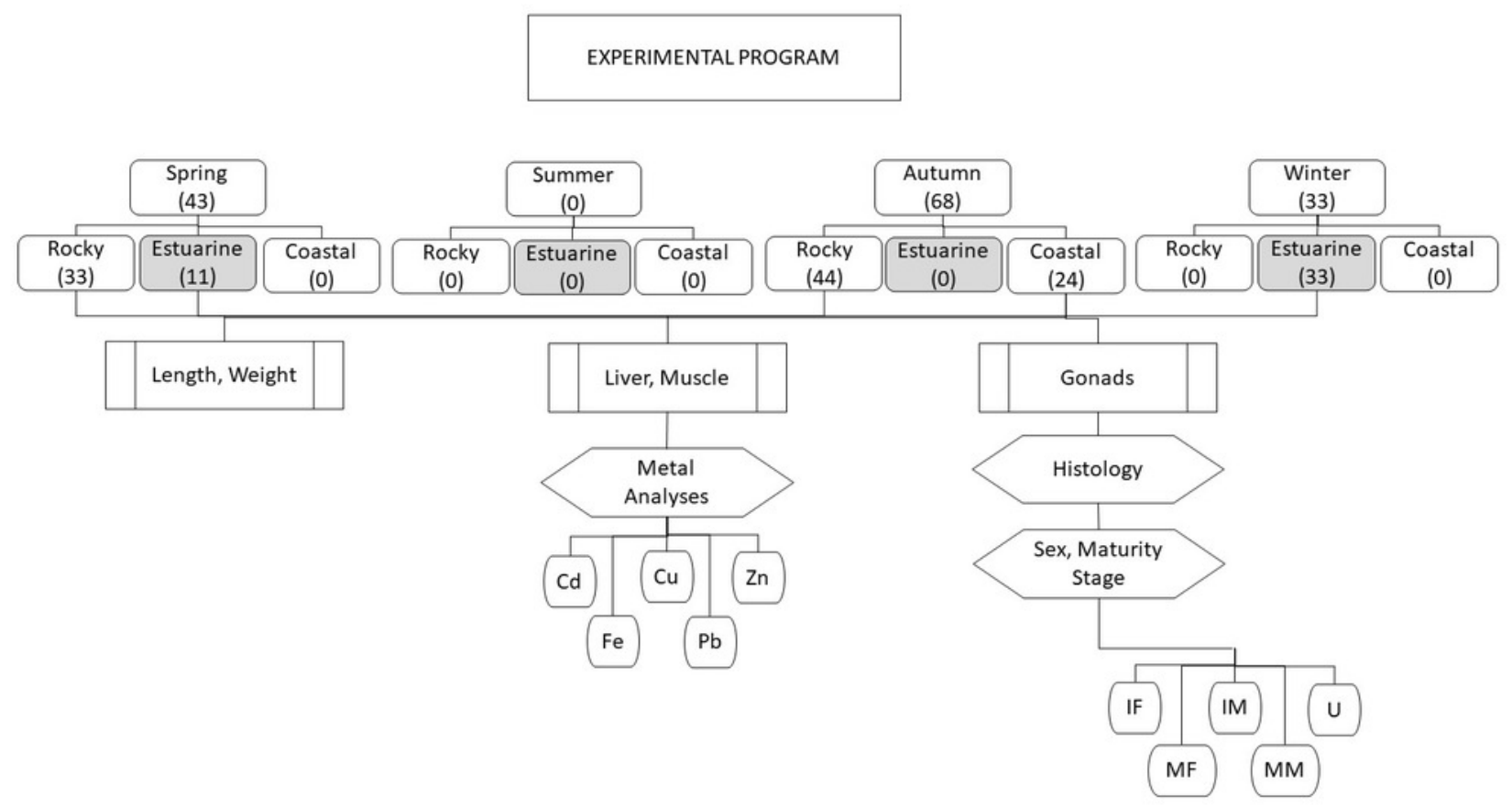


Figure 3

Contribution of copper, cadmium, zinc and iron by consumption of muscle of Totoaba macdonaldi $\left(\mu \mathrm{g} \mathrm{day}^{-1}\right.$ ) to the dietary reference intakes (DRI, National Academies of Sciences, Engineering and Medicine, 2017; dotted line) and referenc 

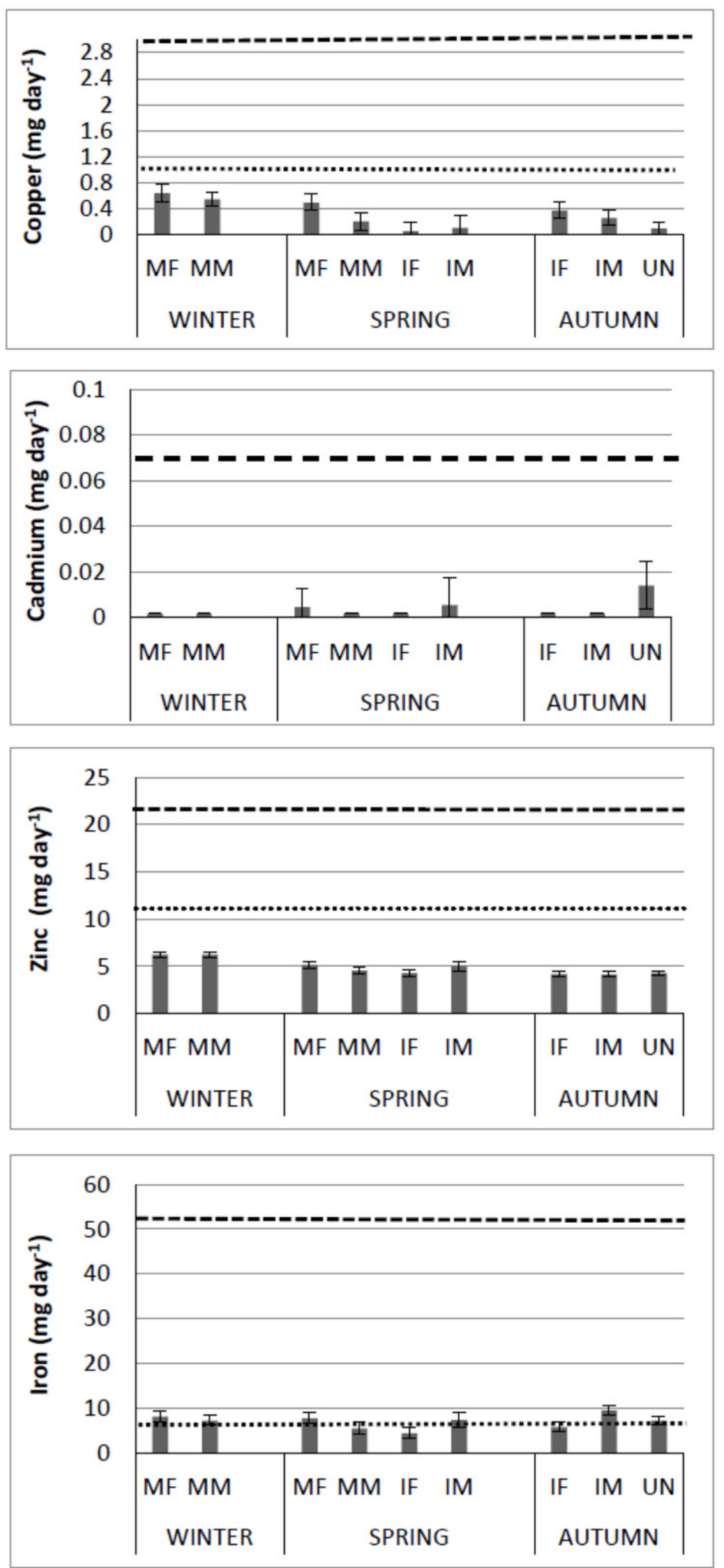

Peer) reviewing PDF | (2020:10:53478:2:0:NEW 10 Feb 2021) 
Figure 4

Histograms of the cumulative distribution of the $5 \%$, mean and $95 \%$ hazard indexes $(\mathrm{HI})$ of copper (Cu), cadmium (Cd), zinc ( $\mathrm{Zn})$ and iron (Fe) for consumption of muscle of Totoaba macdonaldi. 

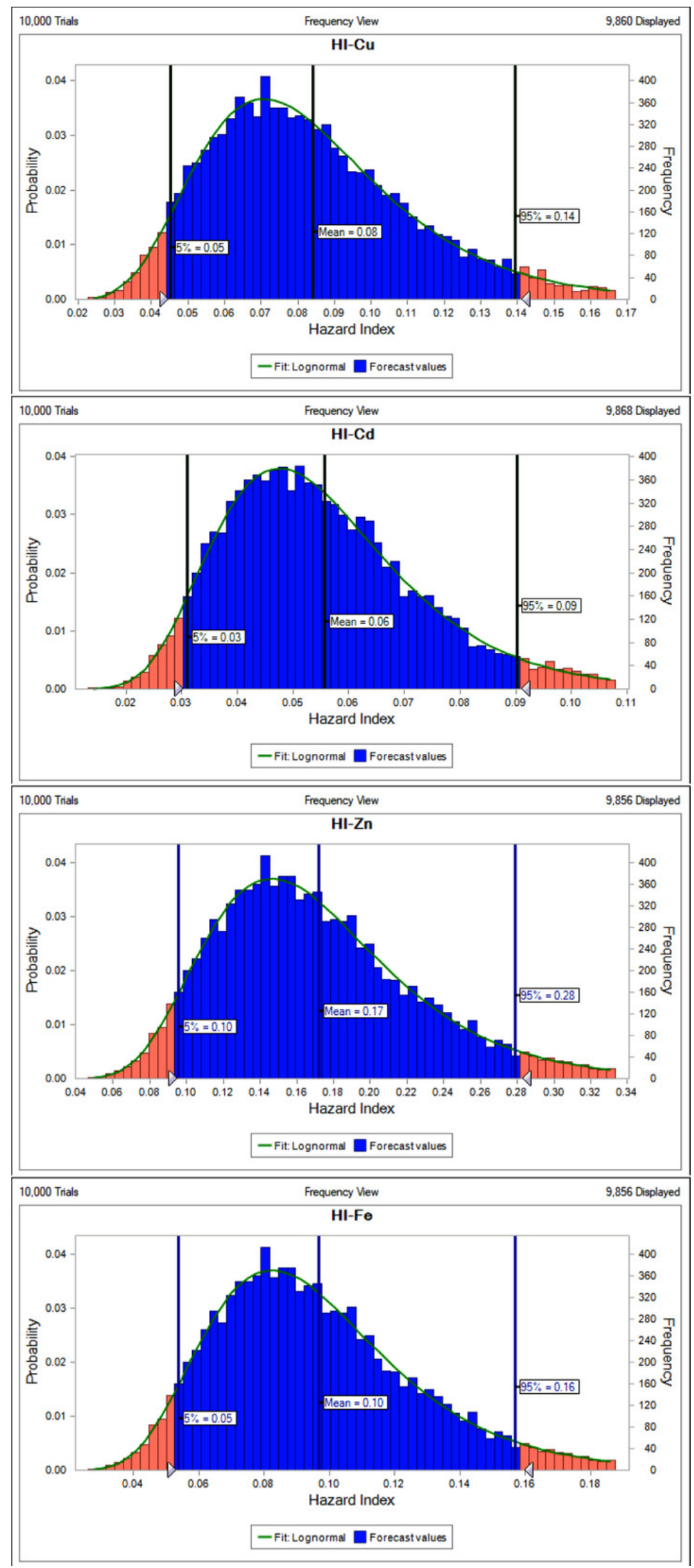

Peer) reviewing PDF | (2020:10:53478:2:0:NEW 10 Feb 2021) 
Figure 5

Cumulative probability distribution curve of hazard index for copper $(\mathrm{Cu})$, cadmium $(\mathrm{Cd})$, zinc $(\mathrm{Zn})$ and iron (Fe) for consumption of Totoaba macdonaldi muscle.

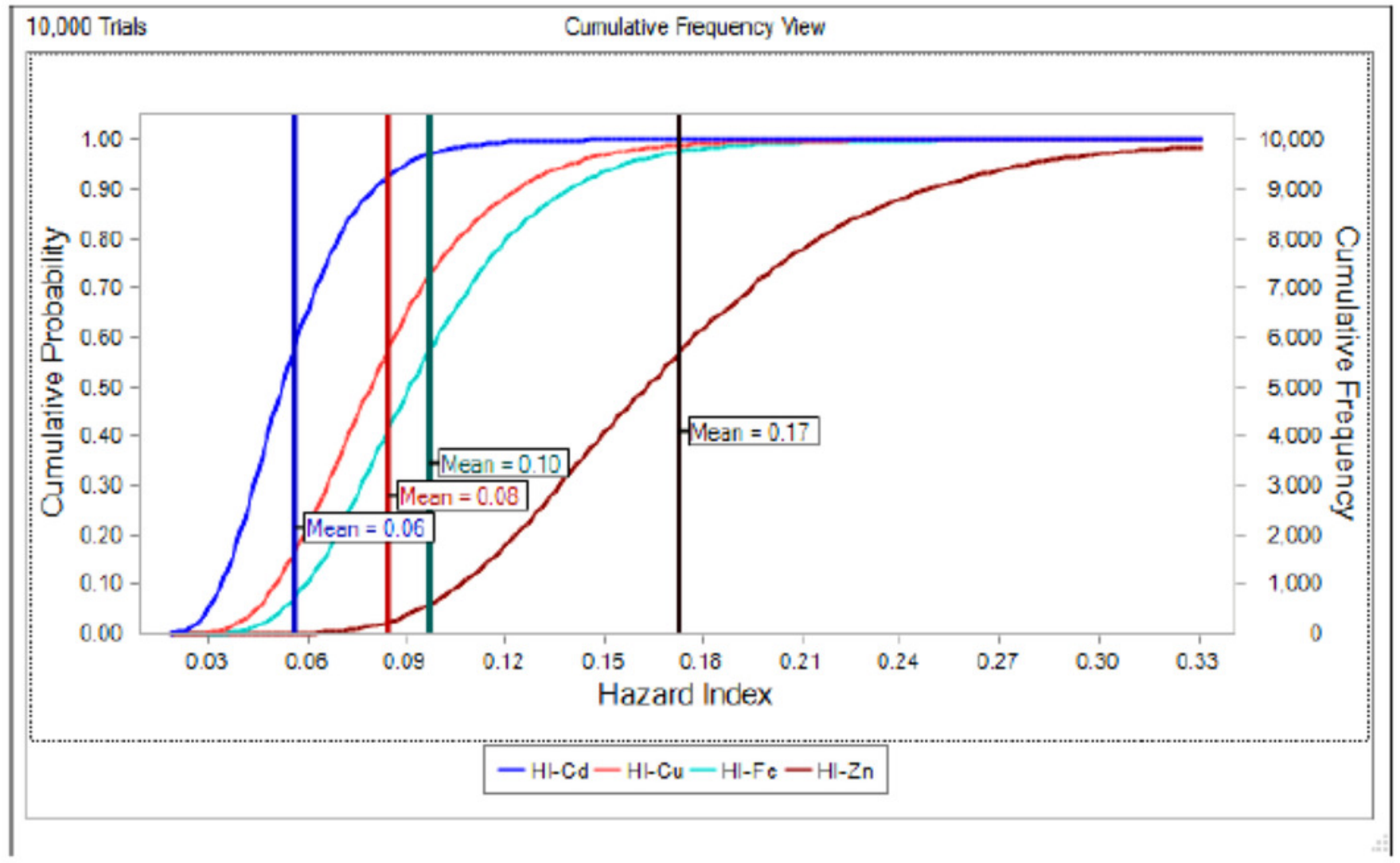


Figure 6

Residuals analysis of the generalized linear models, assuming a gamma error distribution, generated for cadmium (Cd) in liver and muscle of Totoaba macdonaldi in the Gulf of California, Mexico. 


\section{Model 1}

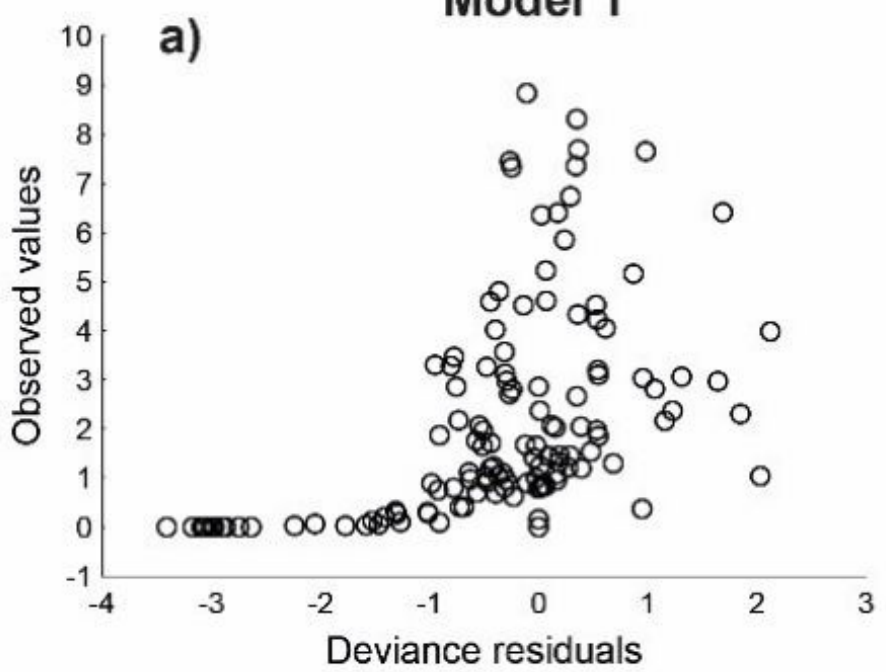

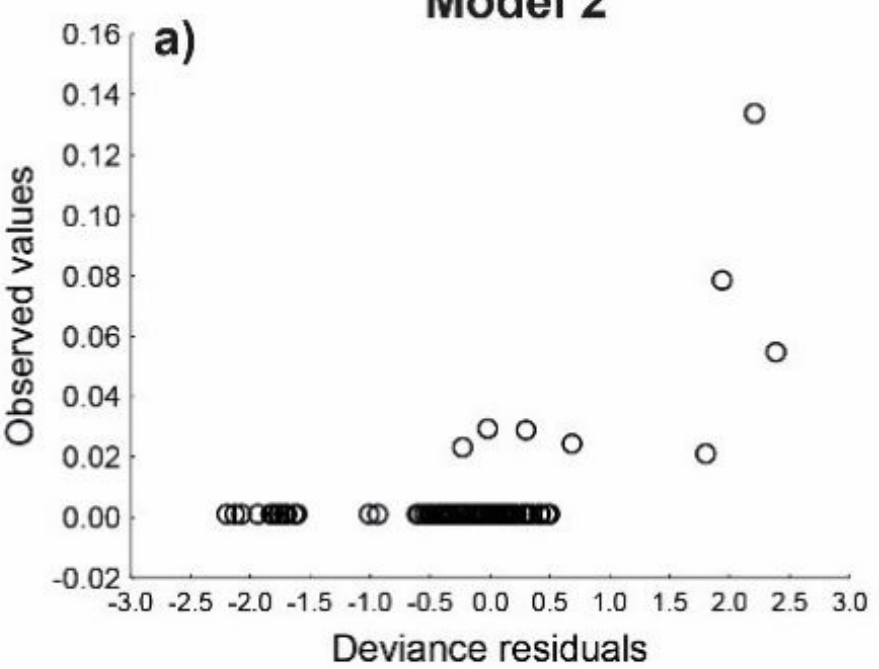

${ }^{0.8}[$ b)

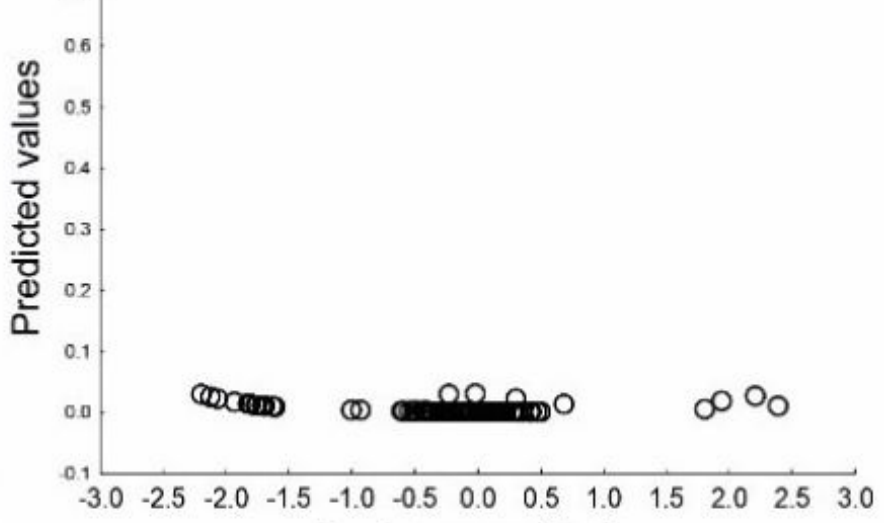

Deviance residuals

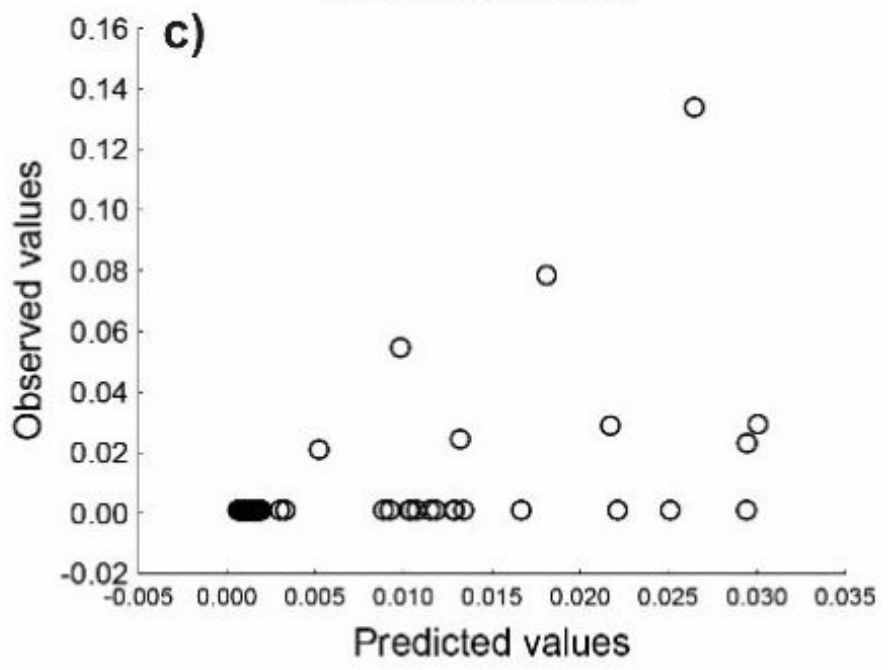

